\title{
( IJBEMP
}

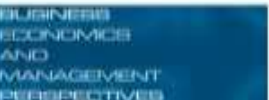

International Journal of Business, Economics and Management Perspectives

Uluslararası İşletme, Ekonomi ve Yönetim Perspektifleri Dergisi

Yıl: 3, Cilt:2, Sayı: 2, Temmuz 2018, s. 55-82

KAMU KURUMLARINDA İÇ DENETIM VE İÇ KONTROL ALGISI: IRAK SÜNNİ VAKFI DIVANI ÜZERİNE BİR ARAŞTIRMA ${ }^{1}$

\section{Mehmet Akif ALTUNAY}

Dr. Öğr. Üyesi, Süleyman Demirel Üniversitesi, İ.İ.B.F, İşletme ABD, Isparta, TÜRKIYYE, e-posta: mehmetaltunay@sdu.edu.tr

Omar Jasim Jameel AL-MASHHADANI

Süleyman Demirel Üniversitesi, S.B.E, İşletme ABD, Isparta, TÜRKIYY, e-posta: omarjasim1982@gmail.com

\footnotetext{
${ }^{1}$ Bu çalışma ikinci yazarın yüksek lisans tezinden türetilmiştir.
} 


\title{
KAMU KURUMLARINDA İÇ DENETIM VE İÇ KONTROL ALGISI: IRAK SÜNNİ VAKFI DIVANI ÜZERINE BİR ARAŞTIRMA
}

\begin{abstract}
ÖZET
İ̧ denetim ve iç kontrol faaliyetleri özel işletmelerde olduğu kadar kamu işletmelerinde de önemli hale gelmiştir.. Kamu kurumlarının kamu kaynaklarını etkili ve verimli kullanılıp kullanılmadığı, hata ve hilelerin yapılıp yapılmadığının iç kontrol ve iç denetim faaliyetleriyle izlenmesi gerekmektedir. Irak kamu kurumlarında çalışan kişilerin iç denetim ve iç kontrol konularındaki algısını tespit etmek için yapılan bu çalışma Irak Sünni Vakfı Divanı çalışanlarına anket uygulanması şeklinde yapılmıştır. Ankete kurumda muhasebe süreçlerinde yer alan personelin katılımı sağlanmıştır. Bu doğrultuda 135 kişi ankete katılmış ve sonuçlar SPSS (SPSS 23) analiz edilmiştir. Yapılan faktör analizinde 6 faktör ortaya çıkmış ve bu faktörlerin demografik değişkenlerle aralarındaki istatistiki açıdan anlamlı bir ilişki bulunup bulunmadĭ̆ı analiz edilmiştir. Sadece risk değerlendirme faktörü ile iş unvanları arasında anlamlı bir ilişki ortaya çıkarken, bu ilişki dışında, faktörlerle demografik değişkenler arasında anlamlı bir ilişki ortaya çıkmamıştır.
\end{abstract}

Anahtar Kelimeler: Kamu Kurumları, İç Denetim, İç Kontrol, Irak Sünni Vakfı Divanı.

JEL Kodlart: M41, M42, M48,

\section{THE INTERNAL AUDIT AND THE INTERNAL CONTROL PERCEPTION IN PUBLIC INSTITUTIONS: A RESEARCH ABOUT IRAQI SUNNI AFFAIRS}

\begin{abstract}
Internal audit and internal control activities are considered important in public enterprises as well as private enterprises. Public institutions should be monitored through internal control and internal audit activities to determine whether public resources are being used effectively and efficiently, whether errors and tricks are made. This study was conducted in order to determine the perception of the internal audit and internal control issues of the people working in Iraqi public institutions by conducting a survey on the employees of the Iraq Sunni Affairs. Personnel involved in the accounting processes in the institution were included in the questionnaire. In this direction, 135 people participated in the survey and the results were analyzed by SPSS (version 23). Factor analysis revealed 6 factors, and these factors were analyzed as to whether there was a relationship with the demographic variables. Only a significant relationship was found between the risk assessment factor and job titles, but no significant relationship was found between the factors and the demographic variables.
\end{abstract}

Keywords: Public Institution, Internal Control, Internal Audit, Iraq Sunni Affairs.

JEL Kodlart: M41, M42, M48, 


\section{GíRiş}

Son y1llarda dünya genelinde yaşanan muhasebe skandallarından sonra iç denetim ile iç kontrol büyük önemi artmıştır. Yatırımcıların hak ve menfaatlerinin garanti altına alınabilmesi ve kurum faaliyetlerinin yine kurum bünyesinde bulunan bağımsız iç denetçiler tarafından denetlenmesi işletmeler açısından mutlak uyulması gereken kurallar haline gelmiştir. Yatırımcılar yatırım yapacakları işletmelerin mali durumları yanında kurumsal yönetim, iç denetim ve iç kontrol faaliyetlerine de dikkat etmektedirler. Bu durum iç denetimin ve kontrolün, özellikle gelişmekte olan ülkelerde, işletmelerin ve yatırımcıların karşılaşabileceği risklerden korunabilmeleri açısından büyük önemi bulunmaktadır.

İç kontrol ile iç denetimin günlük konuşma dilinde hatalı olarak aynı anlamda kullanıldığ 1 görülür. İşletmelerin belirledikleri hedef ve amaçlara etkin bir şekilde ulaşmalarını ve bu amaçlara ulaşılacağına yeterli ölçüde güvence duyulmasını sağlayıcı niteliklere haiz olarak oluşturulan usul ve yöntemlerin bütünü iç kontrol olarak tanımlanmasına karşın, iç denetim bundan farklı olarak; işletme içinde kurulmuş bağımsız bir değerleme fonksiyonu olup, temelde iç kontrol oluşturan kontrol unsurlarının yeterliliğini ve etkinliğini incelemek ve değerlemek suretiyle fonksiyon gören bir kontrol unsurudur (İbiş ve Günal, 2010:10). Dolayısıyla iç kontrol ve iç denetim birbirinden farklı, ancak birbirini tamamlayan iki kavram olarak değerlendirilmelidir (Adiloğlu, 2011:25).

COSO (The Committee on Sponsoring Organizations of The Treadway Commission) tanımına göre iç kontrol, faaliyetlerin etkinlik ve verimliliği, finansal tabloların güvenilirliği, uygulamaların cari mevzuat ve düzenlemelere uyumluluğu konularında hedeflere ulaşllabilirliğe dair makul bir güvence sağlamak amaciyla biçimlendirilen ve bir örgütün yönetim kurulu, yöneticileri ve diğer personeli tarafından uygulanan bir süreçtir (Özbek, 2012:22). İç kontrol, süreç ve iş akışları içine yerleştirilen, kişilerden etkilenen, işletmenin amaçlarına ulaşmasında kullanılan bir araçtır. Makul ölçüde güvenilirlik sağlar. Bu özellikleri ile iç kontrol işletme yönetiminin sorumluluğundadır. Etkinliğinin ve yerindeliğinin değerlendirilmesi için iç denetim faaliyetine ihtiyaç gösterir. Bu nedenle iç kontrol ve iç denetim birbirinden farkl1, ancak birbirini tamamlayan iki kavram olarak değerlendirilmelidir (İbiş ve Günal, 2010:10).

İç denetim, esas olarak, mevcut iç kontrol sisteminin amaçlandığ 1 şekilde işleyip işlemediğini ve bu yönde üst yönetime hangi raporların gönderildiğini inceleyen bir birimdir. İç denetimin temel amacı üst yönetimin sorumluluklarını yerine getirmesine yardımcı olmaktır. İç denetim, "işletmede kontroller arasında en iyi iç ilişkiye ve toplam iç kontrol yapısı içerinde en iyi bileşene nasıl ulaşılabilir" konusunda yönetime yardımcı olacaktır (Kurnaz ve Çetinoğlu, 2010:26). Yöneticiler iç kontrol yapısının kalitesi konusundaki bilgileri iç denetim biriminden alırlar. Bu bilgileri değerlendirmek suretiyle iç kontrol yapısının sağlıklı bir şekilde işlemesini sağlarlar. İşletmede iyi bir iç denetim varlığı iç denetçilerin, iyi bir iç kontrol varlığı ise yöneticilerin başarısıdır (Haftacı, 2014:66). İç denetim, risk yönetimi gibi iç kontrol ile ilişkilendirilmiş ancak bağımsız bir statüye sahip olmalıdır. İç kontrol, iç denetimin bir alt alan adı değildir. Aksine, iç denetim, iç kontrol izleme bileşeninin önemli bir parçasıdır. Yani, iç denetim iç kontrolün bir parçası olarak işlev görür. İç kontrol, operasyonların, dış denetçilerin, iç denetimin ve uygunluk fonksiyonlarının çalışacağı zemindir. Bu arka planın önemini anlamak için, iç denetim, yalnızca iç denetimden sorumlu şirketin yönetimine iyi açıklanmamalı ve bir sistem ve bir dizi süreç olarak görüp anlamak için kurum içi bilinç sağlanmalıdır (Akyel, 2010:12).

\section{LITERATÜR TARAMASI}

El-Baaj (2011) çalışmasında, AL-Qadisiyah Üniversitesi'nde iç kontrol sisteminin değerlendirilmesini, mevcut olan sorunlara uygun çözümlerin önerilmesini ve netice olarak ElKadisiyye Üniversitesi'nin iç kontrol sisteminin geliştirilmesini amaçlamıştır. Çalışmanın kapsamı ElKadisiyye Üniversitesi başkanlığında ve bağlı bulunan fakültelerin denetim birimlerinin iç kontrol ile denetim şubesinde çalışan personelden oluşmaktadır. Çalışma örneklem grubu (50) kişidir. Araştırmacı, üniversite rektörlüğü ile bağlı bulunan fakültelerde iç kontrol ile denetim sorumlularıyla doğrudan görüşmeler yapmakla beraber, araştırmasında gözlem, izleme ve alan ziyaretleri yöntemini uygulamıştır. Çalışma hedeflerini gerçekleştirmek amacıyla özel anket kullanmıştır. Gerekli istatistiksel analiz yapıldıktan sonra çalışma, iç kontrol sistemlerine verilen önemin artırılması, denetim sisteminin kapsamlıdan seçmeliye dönüştürülmesi, faaliyetlerin verimliliğinin değerlendirilmesi ve denetimin geliştirilmesi gibi sonuçlara ulaşmıştır. 
Mohamud (2013) çalışmasında, döviz transfer firmalarında iç denetim ile iç kontrol sistemi uygulamaları arasındaki ilişkiyi incelemekle beraber iç denetim rolü ile iç kontrol seviyesini belirlemeyi hedeflemiştir. Çalışma toplumu, (12) adet döviz transfer şirketinden oluşmaktadır. Çalışma örneklem grubu toplam (69) kişi olmak üzere, döviz transfer firmalarında muhasebeci, maliye müdürü, yönetici ile veznedarı kapsamaktadır. Çalışma hedeflerini gerçekleştirmek üzere betimleyici analitik yaklaşım kullanılarak anket tasarlanmıştır. Çalışmada elde edilen sonuçlara göre, görev ayrımı konusunda bazı sınırlamalar bulunmasıyla döviz transfer firmalarında iç kontrol uygulamalarının etkin olduğu görülmüştür. Ayrıca iç denetim ile iç kontrol sistemi arasında pozitif korelasyon ilişkisi bulunduğu ispatlanmıştır.

Doğan - Burgazlığlu (2015) çalışması, bir hastane işletmesinin iç kontrol sistemin uygulanması üzerinedir. Çalışma sonuçlarına göre mevcut eksikliklerin giderilmesiyle hastanede etkin bir iç kontrol yapısı sağlanacak, böylece kaynakların yanlış kullanımı ve kaybolması önlenecek, hata ve hileler sonucu oluşabilecek kayıplar azalacak, mali tablolarda doğruluk ve güvenilirlik sağlanacak ve hastane içerisinde güvenilir bilgi akışı yoluyla üst yönetimin doğru kararlar vermesi sağlanabilecektir.

Ergin vd. (2016) çalışmalarında Türkiye'de faaliyette bulunan KİT'lerdeki mevcut iç kontrol, iç denetim faaliyetlerinin odak noktasında bulunan KİT denetim personeli tarafindan bu kavramların nasıl algılandığına ve gerçekleştiğine ilişkin bir bakış açısı ortaya koyulmaya çalışılmıştır. Yapılan araştırmada bu kavramların hayat geçirilmesi için öncelikle merkezi yönetimin kararlılığı ve üst yönetimin tam desteği gerekmektedir. Bu anlamda yasal ve idari düzenlemelerde, uygulamaya dönük standartların, rehberlerin ve prosedürlerin eksik bir şekilde yapılandırıldı ̆̆ı, uluslararası entegrasyonda birlik sağlanmadığı görülmektedir. Gerçekçi vizyon ve misyon tanımlamaları yapılarak bilgi ve tecrübenin ön plana alındığı, yetkilendirilmiş ve başarıyı ödüllendirici/özendirici bir üst yönetimin teşekkül ettirilmesi atılacak adımların başında yer almaktadır. Sonuç olarak gelişmiş ülkelerde ölçüt olarak belirlenen uluslararası standartlarda iç kontrol ve iç denetim faaliyetlerinin kurumsal yönetim ilke ve uygulamaları ile bütünlük sağlayacak şekilde yapılandırılması KİT'leri rekabet edilebilir bir ekonomide daha başarılı konuma taşıyacağı söylenebilir.

Özkardeş (2017) çalışmasına göre, kurumsal yönetim fonksiyonlarından bir tanesi olan 'kontrol' faaliyetleri, esas itibariyle şirket içinde oluşturulan iç kontrol sistemi ile sağlanmakta; iç kontrol sisteminin etkin olarak işlem görmesi için de iç denetim uygulanmaktadır. İç denetim, başlarda geleneksel yaklaşım çerçevesinde uygulanır iken; 1980'li yıllarda ABD'de yaşanan firma krizlerinin (Enron vb.) etkisiyle, risk yönetimi de iç denetimin kapsamına girmeye başlamıştır. İç denetim zamanla risk odaklı uygulanmaya başlamış ve bu yaklaşım giderek ağılık kazanmıştır. Çalışmamızda, Türkiye'deki firmaların bu konuya yaklaşımlarının ortaya konması hedeflenmiştir. Bu amaçla, iç kontrol ve iç denetim kavramları ve bunların risk unsuru ile ilişkisi ele alınmış; BISTKURY Endeksine kayıtlı 32 adet şirketin faaliyet raporları temel alınarak iç kontrol, iç denetim ve riskin etkileşimi üzerine içerik analizi yöntemi uygulanmıştır. Çalışma sonucunda; şirketlerin iç kontrol ve iç denetim olgularına verdikleri önem ile risk yönetimine yaklaşımları arasında doğrusal korelasyon bulunduğu; risk yönetimine ağırlık veren şirketlerin iç kontrol ve iç denetime de daha fazla önem verdikleri gözlemlenmiştir.

\section{IRAK SÜNNİ VAKFI DİVANI HAKKINDA GENEL BİLGILER}

Irak Sünni Vakfı Divanı, Irak Bakanlar Kurulu Başkanlığı'na bağlı, kendi tüzel kişiliği olan, bağımsız bir kurumdur. Şekil 1'de Irak Sünni Vakfı Divanı'nın organizasyon şeması yer almaktadır Irak Sünni Vakfı Divanı, Irak'taki Sünni Toplumu ile ilgili işlerde yetkilendirilmiş bir uzmanlık ofisi olarak 1 Ekim 2012 tarihinde, 56 sayılı "Sünni Vakfı Divanının Kuruluşu Hakkında Kanun" ile kurulmuştur. Irak Sünni Vakfı Divanı kanununda yazılı işlemleri yürütmek üzere Bakanlar Kuruluna bağlı olarak faaliyetlerini sürdürmektedir. Tüzel kişiliğe sahip olan Irak Sünni Vakfi Divanı, Başkan tarafindan temsil edilir. Başkan, vakfı politikasının uygulanmasından, yönergelerin hazırlanması ve uygulanmasından, yasaların uygulanmasından ve bunların denetlenmesinden sorumludur. Divan Başkanı, Irak Sünni Vakfı Divanı'nın görevleri ve yetkileri doğrultusunda, talimat, karar ve emirleri yayınlar, Vakfın işleyişine dair şartları belirler.. 


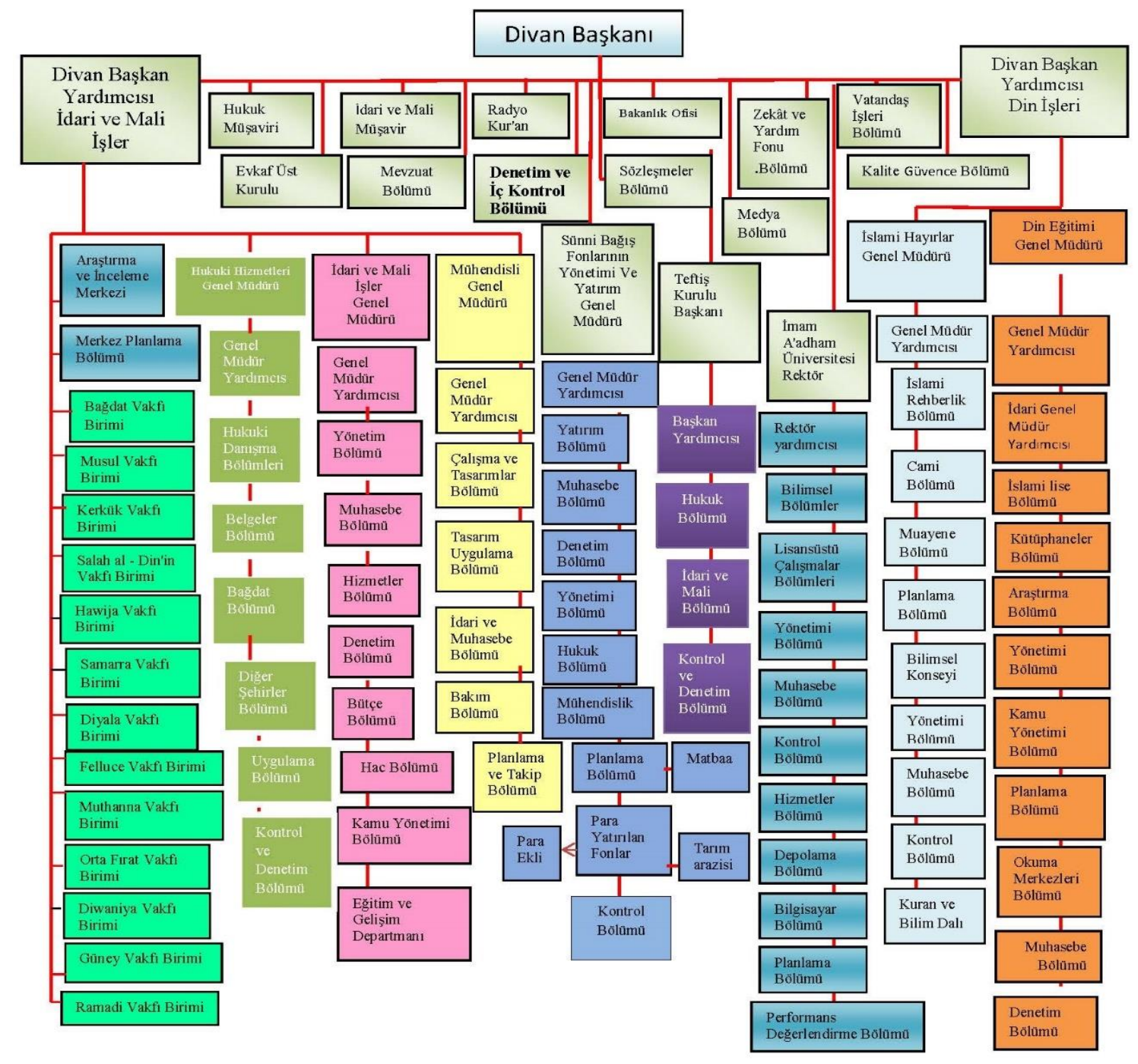

Şekil 1. Irak Sünni Vakfı Divanı Şeması

Kaynak: Irak Sünni Vakfi Divanı, http://sunniaffairs.gov.iq (Son Erişim Tarihi: 01.11.2017)

Irak Sünni Vakfı Divanı’nın birim çalışanları hakkında aşağıdaki bilgiler verilebilir:

a) Her müdürlük, en az bir lisans diplomasına sahip olan ve en az 8 yıllık hizmet süresini doldurmuş olan bir genel müdür (genel direktör) tarafından yönetilir.

b) Her bölümün başında en az bir lisans diplomasına sahip olan ve en az 4 yıllık hizmet süresini doldurmuş olan müdür unvanına sahip bir çalışan bulunur.

c) Bölümde çalışanların sayısı en az 10 kişi, birimde çalışanların sayısı ise en az 3 kişidir.

\subsection{Irak Sünni Vakfı Divanı Müdürlüklerinin Görevleri}

\section{a. İdari ve Mali Genel Müdürlüğ̈̈}

İdari ve Mali Genel Müdürlüğü, Sünni Vakfı Divanı'nın en önemli genel müdürlüğü olup temel görevi vakfın mali işlerinin konsolide edilmesidir. Genel Müdürlük ve Sünni Bağış'a bağlı şehirlerdeki birimlerin mali bütçelerinin hazırlanması ve dağıtılmasından sorumludur. Muhasebe bölümünde 24 adet, iç kontrol bölümünde ise 8 adet personel bulunmaktadır.

\section{b. Din Eğitim Genel Müdürlüğü}


Din Eğitim Genel Müdürlüğü, Irak Sünni Vakfı Divanı'na bağlı ortaöğretim okullarını yöneten kurumdur. Bu genel müdürlüğün amaçlarından biri, İslam dininin yaklaşım ve davranış hedeflerine uyan bir neslin yetiştirilmesidir. Faaliyetleri İslami bir eğitim niteliğindedir ve bu alanda uzmanlaşmış kolejler oluşturarak orta öğretime paralel eğitim vermektedir. Bir genel müdür ve iki genel müdür yardımcısının olduğu bu genel müdürlük, devlet muhasebe sistemine göre faaliyet göstermektedir. Muhasebe bölümünde 15 adet ve kontrol bölümünde ise 4 adet personel çalışmaktadır.

\section{c. İslami Hayır Genel Müdürlüğü}

İslami Hayır Genel Müdürlügü̈nün görevi Irak Cumhuriyeti'nde bulunan Irak Sünni Vakfi Divanı'na ait camilerin işlerini takip etmektir. Bu genel müdürlüğün bir başka görevi ise hayırseverler tarafından yapılan yardımları muhtaç kişiler ile İslami hayır kurumlarına ve camilere ulaştırmaktır. $\mathrm{Bu}$ genel müdürlük, devlet muhasebe sistemine göre faaliyet göstermektedir. Muhasebe bölümünde 13 adet ve kontrol bölümünde ise 4 adet personel çalışmaktadır.

\section{d. İmam AL-ADHAM Üniversitesi}

Sünni Vakfın Genel Müdürlüklerinden biri olan İmam ALADHAM Üniversitesi, Sünni Vakfı Divanı'na maddi olarak bağlıdır. İdari olarak Irak yükseköğretim bakanlığına bağlı olup Devlet muhasebe sistemine göre faaliyet göstermektedir. Muhasebe bölümünde 13 adet ve kontrol bölümünde ise 4 adet personel çalışmaktadır.

\section{e. Teftiş Genel Müdürlüğü}

Teftiş Genel Müdürlüğü, Irak Sünni Vakfı Divanı içerisinde inceleme gerektiren tüm işlerden sorumludur. Bu genel müdürlük devlet muhasebe sistemine göre çalışır. Çoğu çalışanı yasalar ile muhasebe ve denetim ilkelerinde tecrübeye sahiptir. İdari ve mali bölümde 8 kişi çalışmakta olup ayrıca bir de kontrol bölümü mevcuttur. Bu Genel Müdürlük Sünni Vakfındaki tüm çalışma komiteleri içerisinde yer almaktadır. Teftiş Genel Müdürlüğü, Denetim ve İç Kontrol Bölümü tarafindan yürütülen denetim çalışmalarının çoğuna katılmaktadır.

\section{f. Sünni Vakfi Yönetimi ve Yatırım Fonları Genel Müdürlüğü}

Irak Sünni Vakfı Divanı bağlı birimlerden biri olan bu genel müdürlük, Sünni Vakfı, Sünni Bağış'a ait tüm mülklerden sorumludur (arsalar, binalar ve diğer varlıklar). Bu genel müdürlükte Tekdüzen muhasebe sistemi kullanılmaktadır. Irak Sünni Vakfı Divanı fonlarının Şeriat hükümlerine ve vakıf koşullarına uygun olarak yönetimi ile sorumludur. Muhasebe Bölümünde 16 kişi, Denetim ve İç kontrol Bölümünde ise 7 kişi çalışmaktadır. Federal Denetim Bürosu tarafından yayımlanan mevzuata uygun olarak çalışır.

\section{g. Mühendislik Genel Müdürlüğü}

Sünni Vakfı Divanına bağlı genel müdürlüklerden biridir. Bu Genel Müdürlük devlet muhasebe sistemine göre çalışır. Bu genel müdürlük genel mali bütçe ve yatırım bütçesi olmak üzere iki bütçeye sahiptir. Genel Müdürlüğün muhasebe bölümü ise bütçe ayrımına paralel olarak iki bölümden oluşmakta ve toplam 14 personel içermektedir. Sünni Vakfı Divanı'nın özel projeleri için bir yatırım bütçesi mevcuttur. Genel Müdürlüğün tek bir iç kontrol bölümü mevcut olup 5 çalışanı vardır.

\section{h. Hukuki Hizmet Genel Müdürlüğü}

Hukuki Hizmet Genel Müdürlüğü, hukuk işlemlerinde uzmanlaşmıştır. Bu Genel Müdürlük devlet muhasebe sistemine göre çalışır. Muhasebe bölümünde 11 adet ve kontrol bölümünde ise 3 adet personel bulunmaktadır.

\subsection{Denetim ve İç Kontrol Bölümü ve Alt Bölümleri}

Denetim ve İç Kontrol Bölümü, Irak Sünni Vakfı Divanı'nın en önemli bölümlerinden biri olarak kabul edilmektedir. Bu bölüm, Federal Denetim Bürosu tarafindan yayımlanan yönetmelikler doğrultusunda faaliyetlerini ve çalışmalarını yürütmektedir. Genel Müdürlükteki İç Denetim Bölümleri ve Sünni Vakfı Divanı İç Kontrol ve Denetim Bölümü, doğrudan doğruya Irak Sünni Vakfı Divanı Başkanına bağlıdır.

\section{ARAŞTIRMA TASARIMI VE YÖNTEMI}

$\mathrm{Bu}$ araştırma Irak Cumhuriyeti, Irak Sünni Vakfı Divanı kurumunun denetim ve muhasebe bölümlerinin yönetici ve çalışanlarına anket uygulaması şeklinde yapılmıştır. Bu araştırma ile Irak kamu 
kurumlarında iç denetim ve iç kontrol unsurlarına yönelik algı ve tutumlarının tespit edilmesi amaçlanmıştır.

$\mathrm{Bu}$ araştırmanın bir başka hedefi de iç denetim ve iç kontrol alanlarındaki gelişmelerin Irak Sünni Vakfı Divanı'ndaki iç denetim ve iç kontrol sistemine olan yansımalarının ortaya konulmasıdır.

Irak Sünni Vakfı Divanı'nda çalışanlara ve yöneticilerine yönelik bir anket yapılmıştır. Anket verilerini analiz etmek için ise sosyal bilimler için çok değişkenli istatistik (SPSS 23) programı kullanılmıştır.

\section{3. Ölçek ve Güvenilirliği}

Araştırmanın amacına ulaşması amacıyla anket formu ${ }^{2}$ hazırlanmıştır. Anketin hedef kitlesi olarak Irak’taki Sünni Vakfı Divanı muhasebe ve denetim bölümü personeli belirlenmiştir. Anket formu ulaşılmak istenen amaca yönelik olarak üç bölümden oluşmuştur.

Birinci bölüm; katılımcıların demografik özelliklerini belirlemeye yönelik 6 sorudan oluşmaktadır.

İkinci bölüm; katılımcıların Irak Sünni Vakfı Divanı 5 sorudan oluşmaktadır. sonraki 5 soru iç denetim, sonraki 5 soru risk değerlendirme bölümüni, sonraki 5 soru bilgi iletişim, sonraki 5 soru iç denetimin bağımsızlığı, sonraki 5 soru iç denetim birimi üyelerinin mesleki yeterliliği öçlmeye yönelik sorulardan oluşmaktadır. Bu sorulara verilen cevaplar, kesinlikle katılıyorum, katılıyorum, kısmen katılıyorum, katılmıyorum ve hiç katılmıyorum şeklindeki cevaplardan oluşmaktadır.

Üçüncü bölüm sadece iç denetçilere yöneliktir. İç denetçilerle ilgili 9 sorudan oluşmaktadır. Bu sorulara verilen cevaplar, kesinlikle katılıyorum, katılıyorum, kısmen katılıyorum, katılmıyorum ve hiç katılmıyorum şeklindeki cevaplardan oluşmaktadır.

Ölçek, kullanım öncesinde güvenilirlik ve geçerlilik açısından test edilmelidir. Ölçeğin güvenilirliği, aynı numunenin ölçeğin farklı zamanlarında ne kadar uygulandığını ve aynı sonuçların verildiğini göstermektedir. Bu çalışmada, güvenilirlik analizi yapıldığında Cronbach Alpha değeri kullanılmıştır. Cronbach alfa değeri 0.70 veya daha büyük olduğunda, ölçeğiniz oldukça güvenilir olarak kabul edilir (Güriş ve Astar, 2015:282).

Tablo 2'de, Cronbach Alpha göstergeleri sunulmuştur. Tüm sorulara yapılan Cronbach's Alfa istatistiği 0,940 olarak bulunmuş olup anketin güvenilirliği son derece yüksek olduğunu göstermektedir. Tüm faktörlere ait sorular arasındaki Cronbach's Alpha değerleri verilmiştir. Çalışma aracının genellikle yüksek stabilite katsayısı ile karakterize edildiğini göstermektedir.

Tablo 2. Faktörlerin Güven Testini

\begin{tabular}{|l|c|c|}
\hline & Faktörler & Cronbach's Alpha'nın değeri \\
\hline 1 & Bilgi ve İletişim & 0,880 \\
\hline 2 & Risk Değerlendirme & 0,899 \\
\hline 3 & Güvence Sağlama & 0,867 \\
\hline 4 & Bağımsızlı & 0,814 \\
\hline 5 & Kontrol Faaliyetleri & 0,719 \\
\hline 6 & Kontrol Ortamı & 0,707 \\
\hline & Tüm Faktörler & 0,940 \\
\hline
\end{tabular}

\subsection{Araştırmanın Kısıtları}

Bu çalışmada Irak Sünni Vakfı Divanı çalışanlarına yüz yüze veya internet aracıllğıyla bir anket ugulanmıştır. Anket çalışmalarının geneline ait olan kısıtların yanı sıra kapsam, zaman ve katılımcılar açısından bazı kısıtlar bulunmaktadır. Bu kısıtlar:

\footnotetext{
${ }^{2}$ Bu anket formu, Omar İzz El-Din, “The Impact of Internal Control System Effectiveness on Internal Auditor Performance: A Field Study on Jordanian Private Universities", Middle East University, Jordan temel alınarak hazırlanmıştır. Sorularda ekleme, çıkarma veya diğer değişiklikler yapılmıştır.
} 
- Araştırmanın Irak Cumhuriyeti kurumlarından sadece Irak Sünni Vakfı Divanı çalışanlarına uygulanmas1,

- Bütün anketlerde olduğu gibi ankete katılanlardan kaynaklanan eksikliklerin anket sonuçlarını etkileyebilecek faktörlerden olması,

- Yüzyüze uygulanan anketlerde katılımcılara gerekli açıklamalar yapılmış ancak, internet üzerinden yapılan anketlerde katılımcılara açıklamalarda bulunulmamıştır.

\subsection{Araştırmanın Hipotezleri}

Aşağıda, literatürden de yararlanarak oluşturulan çalışmanın hipotezleri verilmiştir:

HA1. İç kontrol unsurlarından bilgi ve iletişim unsuru ile çalışanın eğitim durumu arasında istatistik olarak anlamlı bir ilişki vardır.

HA2. İç kontrol unsurlarından risk değerlendirme unsuru ile çalışanın eğitim durumu arasında istatistik olarak anlamlı bir ilişki vardır.

HA3. İç denetim unsurlarından güvence sağlama unsuru ile çalışanın eğitim durumu arasında istatistik olarak anlamlı bir ilişki vardır.

HA4. İç denetim unsurlarından bağımsızlık unsuru ile çalışanın eğitim durumu arasında istatistik olarak anlamlı bir ilişki vardır.

HA5. İç kontrol unsurlarından kontrol faaliyetleri unsuru ile çalışanın eğitim durumu arasında istatistik olarak anlamlı bir ilişki vardır.

HA6. İç kontrol unsurlarından kontrol ortamı unsuru ile çalışanın eğitim durumu arasında istatistik olarak anlamlı bir ilişki vardır.

HA7. İç kontrol unsurlarından bilgi ve iletişim unsuru ile çalışanın deneyim yılı arasında istatistik olarak anlamlı bir ilişki vardır.

HA8. İç kontrol unsurlarından risk değerlendirme unsuru ile çalışanın deneyim yılı arasında istatistik olarak anlamlı bir ilişki vardır.

HA9. İç denetim unsurlarından güvence sağlama unsuru ile çalışanın deneyim yılı arasında istatistik olarak anlamlı bir ilişki vardır.

HA10. İç denetim unsurlarından bağımsızlık unsuru ile çalışanın deneyim yılı arasında istatistik olarak anlamlı bir ilişki vardır.

HA11. İç kontrol unsurlarından kontrol faaliyetleri unsuru ile çalışanın deneyim yılı arasında istatistik olarak anlamlı bir ilişki vardır.

HA12. İç kontrol unsurlarından kontrol ortamı unsuru ile çalışanın deneyim yılı arasında istatistik olarak anlamlı bir ilişki vardır.

HA13. İç kontrol unsurlarından bilgi ve iletişim unsuru ile çalışanın iş ünvanı arasında istatistik olarak anlamlı bir iliş̧ki vardır.

HA14. İç kontrol unsurlarından risk değerlendirme unsuru ile çalışanın iş ünvanı arasında istatistik olarak anlamlı bir ilişki vardır.

HA15. İç denetim unsurlarından güvence sağlama unsuru ile çalışanın iş ünvanı arasında istatistik olarak anlamlı bir ilişki vardır.

HA16. İç denetim unsurlarından bağımsızlık unsuru ile çalışanın iş ünvanı arasında istatistik olarak anlamlı bir ilişki vardır.

HA17. İç kontrol unsurlarından kontrol faaliyetleri unsuru ile çalışanın iş ünvanı arasında istatistik olarak anlamlı bir ilişki vardır.

HA18. İç kontrol unsurlarından kontrol ortamı unsuru ile çalışanın iş ünvanı arasında istatistik olarak anlamlı bir ilişki vardır.

HA19. İç kontrol unsurlarından bilgi ve iletişim unsuru ile çalışanın aldığı kurs sayısı arasında istatistik olarak anlamlı bir ilişki vardır.

HA20. İç kontrol unsurlarından risk değerlendirme unsuru ile çalışanın aldığı kurs sayısı arasında istatistik olarak anlamlı bir ilişki vardır.

HA21. İç denetim unsurlarından güvence sağlama unsuru ile çalışanın aldığı kurs sayısı arasında istatistik olarak anlamlı bir ilişki vardır.

HA22. İç denetim unsurlarından bağımsızlık unsuru ile çalışanın aldığı kurs sayısı arasında istatistik olarak anlamlı bir ilişki vardır. 
HA23. İç kontrol unsurlarından kontrol faaliyetleri unsuru ile çalışanın aldığı kurs sayısı arasında istatistik olarak anlamlı bir ilişki vardır.

HA24. İç kontrol unsurlarından kontrol ortamı unsuru ile çalışanın aldığı kurs sayısı arasında istatistik olarak anlamlı bir ilişki vardır.

\section{6. Örneklem}

Bu araştırma, Irak Sünni Vakfı Divanı ${ }^{3}$ kurumunun denetim ve muhasebe bölümlerinin yönetici ve çalışanlarını kapsamaktadır. Irak Sünni Vakfı Divanı'nda ulaşılmak istenen kişiler ve elde edilen veri sayısı Tablo 3'te sunulmuştur.

Tablo 3. Araştırmanın Kapsamı

\begin{tabular}{|c|c|c|c|c|c|c|}
\hline $\begin{array}{c}\text { Çalışma } \\
\text { Grupları }\end{array}$ & $\begin{array}{c}\text { Çalışan } \\
\text { Kişi Sayısı }\end{array}$ & $\begin{array}{c}\text { Ulaşılan } \\
\text { Kişi Sayısı }\end{array}$ & $\begin{array}{c}\text { Dağıtılan } \\
\text { Anket Sayısı }\end{array}$ & $\begin{array}{c}\text { Alınan } \\
\text { Anket } \\
\text { Sayısı }\end{array}$ & $\begin{array}{c}\text { Geçersiz } \\
\text { Anket Sayısı }\end{array}$ & $\begin{array}{c}\text { Analizi } \\
\text { Yapılan Anket } \\
\text { Sayısı }\end{array}$ \\
\hline Yönetici & 13 & 13 & 11 & 11 & 0 & 11 \\
\hline $\begin{array}{c}\text { Muhasebe } \\
\text { Bölümü }\end{array}$ & 108 & 108 & 77 & $47^{*}$ & 1 & 46 \\
\hline $\begin{array}{c}\text { Iç Denetim } \\
\text { Bölümü }\end{array}$ & 61 & 61 & 60 & $54^{*}$ & 0 & 54 \\
\hline $\begin{array}{c}\text { İc Kontrol } \\
\text { Bölümü }\end{array}$ & 53 & 53 & 43 & $26^{*}$ & 2 & 24 \\
\hline Toplam & 235 & 235 & 191 & 138 & $3^{* *}$ & 135 \\
\hline
\end{tabular}

* Muhasebe bölümünden 4 kişi, iç denetim bölümünden 5 kişi ve iç kontrol bölümünden 1 kişiye (görevleri gereği şehir veya ülke dışında oldukları için) internet üzerinden oluşturulan anket formu ile ulaşılmıştır. ** Anketin tek seçenekli cevaplarına birden fazla seçeneği işaretleyerek cevap verildiği için bu anketler değerlendirmeye alınmamıştır.

\subsection{Verilerin Toplanması ve Analizi}

Irak Sünni Vakfı Divanı bünyesinde yer alan tüm çalışma gruplarını içermekte ve ankete katılanlar muhasebe, denetim ve iç kontrol bölümlerinde çalışanların yanı sıra tüm Yönetici içermektedir. Ankete toplam 135 kişi katılmıştır.

Sorulara verilen cevaplara 5'li Likert ölçeği şeklindeki rakamlara yapılan faktör analizi sonucunda 6 tane özdeğeri 1'den büyük olan faktör belirlenmiştir. Bartlett ki-kare of sphericity ve KMO test istatistiklerine bakılarak verilerin faktör analizine uygun olduğu bulunmuştur. KolmogorovSmirnov normallik testi sonucunda faktörleri oluşturan sorulara verilen puan ortalamalarının dağılımı normal olmadığından dolayı tüm analizlerde parametrik olmayan testler kullanılmıştır. Grup seviye sayısı 2 olduğunda Mann-Whitney U testi, grup seviye sayısı 2 den fazla olduğunda Kruskal-Wallis testi ve Bonferroni-Dunn testi uygulanmıştır. Anketin güvenilirliği ise Cronbach's Alfa test istatistikleri kullanılarak ölçülmüştür.

Çalışmada anket sorularına verilen cevaplar sayı ve yüzde halinde tablolarda sunulmuştur.

Herkese sorulan iç denetim ve iç kontrol ile ilgili 30 soruya verilen 5'li Likert şeklindeki rakamlara yapılan faktör analizi sonucunda öz değeri 1'den büyük olan 6 tane faktör belirlenmiştir. Faktör analizinde açıklayıcı metot olarak temel bileşenler analizi veri döndürme yöntemi olarak da Varimax yöntemi kullanılmıştır. Yükü 0,5 ' den büyük olan soruların hangi faktöre girdikleri Tablo (14) üzerinde gösterilmiştir. Tüm sorulara ve her bir faktöre düşen sorulara verilen cevaplara yapılan Cronbach's Alfa test istatistiği ile sorulara verilen cevapların güvenilirliği yani anketin güvenilirliği test edilmiştir. Faktör analizinin ön şartları olan Bartlett ki-kare of sphericty ve KMO test istatistikleri analize başlamadan önce incelenmiş ve ön şartların sağlandığı tespit edilmiştir. Faktör analizi sonucunda oluşan 6 faktörün her birine düşen soruların puan ortalamaları alınmış ve bu verilere demografik

\footnotetext{
${ }^{3}$ Bu araştırmanın Irak Sünni Vakfı Divanı üzerine yapılmasının amacı, çalışmayı yapan öğrencinin bu kurumun çalışanı olması dolayısıyla verilerin kolay toplanılabileceği düşüncesidir.
} 
sorularda ki cinsiyet, eğitim durumu, yaş v.b. soruların seviye ortalamaları arasında ki farklılıkların belirlenmesinde parametrik olmayan yöntemler kullanılmıştır.

Bunun nedeni ise 6 faktöre ait verilere ayrı ayrı yapılan Kolmogorov-Smirnov normallik testi sonucunda parametrik testlerin ön şartları sağlamadığı görülmüştür. Bundan dolayı seviye sayısı 2 olan (cinsiyet gibi) demografik soruların seviyeleri arasındaki farklılıkların belirlenmesinde Mann-whitney U testi, seviye sayısı 2'den fazla olan (yaş gibi) demografik soruların seviyeleri arasındaki farklıklıkların belirlenmesinde Kruskal-Wallis testi kullanılmıştır. Kruskal-Wallis testi sonucunda seviye Rank Ortalamaları arasındaki fark istatistik olarak önemli bulunduğunda hangi seviyelerin birbirinden farklı olduğunu ise Bonferroni-Dunn testi ile saptanmıştır.

\section{ARAŞTIRMA SONUÇLARI VE SONUÇLARIN DEĞERLENDİRILMESI}

\subsection{Demografik Veriler ve Değerlendirilmesi}

Araştırmaya katılan Irak Sünni Vakfı Divanı çalışanlarının genel özelliklerini belirlemek amacıyla hazırlanan sorulara ilişkin elde edilen bulgular ve frekans dağılımları tablolar halinde verilmiştir. Katılımcıların cinsiyetlerine ilişkin veriler Tablo 4'da verilmiştir.

Tablo 4. Katılımcıların Cinsiyetine İlişkin Veriler

\begin{tabular}{|c|c|c|}
\hline Katılınan Cinsiyeti & Katılımcı sayısı & Yüzde \\
\hline Erkek & 73 & $\% 54,1$ \\
\hline Kadın & 62 & $\% 45,9$ \\
\hline Toplam & 135 & $\% 100$ \\
\hline
\end{tabular}

Tablo 4'te de görüldüğü üzere ankete katılanların yarıdan az fazlasını $(\% 54,1)$ erkekler oluşturmaktadır. Kadınların oranı $(\% 45,9)$ ise yine yarıya yakındır.

Katılımcıların yaşına ilişkin veriler Tablo 5 'te verilmiştir.

Tablo 5. Katılımcıların Yaş Aralığına İlişkin Veriler

\begin{tabular}{|c|c|c|}
\hline Katılınan Yaşı & $\begin{array}{c}\text { Katılımcı } \\
\text { sayısı }\end{array}$ & Yüzde \\
\hline 30 yaş ya da daha az & 46 & $\% 34,1$ \\
\hline $31-35$ yaş arası & 20 & $\% 14,8$ \\
\hline $36-40$ yaş arası & 29 & $\% 21,5$ \\
\hline $41-45$ yaş arası & 15 & $\% 11,1$ \\
\hline 46 yaş ve üstü & 25 & $\% 18,5$ \\
\hline Toplam & 135 & $\% 100$ \\
\hline
\end{tabular}

Tablo 5'te, katılımcıların yaş aralıklarına ilişkin veriler yer almaktadır. Buna göre katılımcıların 1/3'ünü 30 yaşın altındakiler oluştururken, yarıya yakınını orta yaş sayılan 31-45 yaş arası katılımcılar oluşturmaktadır.

Katılımcıların deneyim yıllarına ilişkin veriler Tablo 6'da verilmiştir.

Tablo 6. Katılımcıların Deneyim Yıllarına İlişkin Veriler

\begin{tabular}{|c|c|c|}
\hline Katılınan Deneyim Yıllarına & $\begin{array}{c}\text { Katılımcı } \\
\text { sayısı }\end{array}$ & Yüzde \\
\hline 5 yıl veya daha az & 42 & $\% 31,1$ \\
\hline 6-10 yıl arasında & 48 & $\% 35,6$ \\
\hline 11-15 yıl arasında & 28 & $\% 20,7$ \\
\hline 16 yıl ve üstü & 17 & $\% 12,6$ \\
\hline Toplam & 135 & $\% 100$ \\
\hline
\end{tabular}

Tablo 6'da, katılımcıların deneyim yıllarına göre dağılımları yer almaktadır. Buna göre ankete katılanlar. Deneyim yılı temel alındı̆̆ında, katılımcıların \%31,1'nin 5 yıl veya daha az, \%35,6'nın 610 yıl arasında, \%20,7'nün 11-15 yıl arasında, \%12,6'nın 16 yıl ve üstü olduğu görülmektedir.

Tablo 5 ve Tablo 6 verileri birlikte değerlendirildiğinde katılımcıların yaklaşık 2/3'ünün deneyimli kişiler olduğu söylenebilir.

Katılımcıların eğitim durumlarına ilişskin veriler Tablo 7'de verilmiştir. 
Tablo 7. Katılımcıların Eğitim Durumlarına İlişkin Veriler

\begin{tabular}{|c|c|c|}
\hline Katılınan Eğitim Durumları & Katılımcı sayısı & Yüzde \\
\hline Lise & 22 & $\% 16,3$ \\
\hline Ön lisans & 21 & $\% 15,6$ \\
\hline Lisans & 83 & $\% 61,5$ \\
\hline Lisans üstü & 9 & $\% 6,7$ \\
\hline Toplam & 135 & $\% 100$ \\
\hline
\end{tabular}

Tablo 7'ye göre ankete katılanlar büyük oranda lisans mezunudur $(\% 61,5)$.

Katılımcıların iş ünvanına ilişkin veriler Tablo 8'de verilmiştir.

Tablo 8. Katılımcıların İş Ünvanına İlişskin Veriler

\begin{tabular}{|c|c|c|}
\hline Katılınan İş Ünvanı & $\begin{array}{c}\text { Katılımcı } \\
\text { sayısı }\end{array}$ & Yüzde \\
\hline Memur & 36 & 26,7 \\
\hline Muhasebeci & 45 & 33,3 \\
\hline Muhasebe Denetçisi & 32 & 23,7 \\
\hline Yönetici & 22 & 16,3 \\
\hline Toplam & 135 & $\% 100$ \\
\hline
\end{tabular}

Tablo 8'de de görüleceği üzere katılımcıların memur, muhasebeci, muhasebe denetçisi ve yöneticilerden oluşmaktadır. Klasik bir kamu kurumu organizasyon yapısına uygun bir katılımcı dağılımı söz konusudur. Oran olarak en az üyesi olan grup yöneticiler olarak öne çıkmaktadır. En fazla üyesi olan grup da yönetcilerin iki katı kadar olan muhasebecilerdir. Memur ve muhasebe denetçisi grupları da sayıca birbirine yakın olmakla birlikte muhasebecilerden az, yöneticilerden fazladır.

İşletmelerde sürekli aynı işleri aynı şekilde yapmaktan kaynaklanan ve çoğu zaman alışkanlık olarak ifade edilen iş yapma şekillerinin işletmeleri başarısızlığa uğratması olasıdır. Bu nedenle özel veya kamu işletmeleri çalışanlarının bilgi ve yetkinliklerini artırmak amacıyla onları gerek kendi bünyelerinde gerekse işletme dışında bazı eğitimlere/kurslara gönderirler. Gün geçtikçe gelişen ve değişen iş dünyasının gerisinde kalmamak için bu eğitimler çok önemli olmaktadır. Alınan eğitimler her ne kadar denetim temalı da olsa, özü itibariyle iç kontrol sisteminin etkinliğinin artırılarak hata ve hilelerin azaltılması amaçlanmaktadır.

İş ünvanları ile alınan eğitimler arasındaki ilişki Tablo 9'da verilmiştir.

Tablo 9. Katılımcıların Eğitim Durumu ile İş Ünvanlarına İlişkin Karşılaştırmalı Veriler

\begin{tabular}{|c|c|c|c|c|c|c|c|c|c|c|c|}
\hline & \multicolumn{8}{|c|}{ Katılımcıların İş Ünvanı } & \multirow{2}{*}{\multicolumn{2}{|c|}{ Toplam }} \\
\hline & & \multicolumn{2}{|c|}{ Memurlar } & \multicolumn{2}{|c|}{ Muhasebeci } & \multicolumn{2}{|c|}{$\begin{array}{l}\text { Muhasebe } \\
\text { Denetçisi }\end{array}$} & \multicolumn{2}{|c|}{ Yönetici } & & \\
\hline \multirow{4}{*}{$\begin{array}{l}\text { Katılımcıların } \\
\text { Eğitim } \\
\text { Durumları }\end{array}$} & Lise & 13 & $59 \%$ & 2 & $9 \%$ & 4 & $18 \%$ & 3 & $14 \%$ & 22 & $100 \%$ \\
\hline & Ön lisans & 4 & $19 \%$ & 8 & $38 \%$ & 8 & $38 \%$ & 1 & $5 \%$ & 21 & $100 \%$ \\
\hline & Lisans & 18 & $22 \%$ & 32 & $39 \%$ & 19 & $23 \%$ & 14 & $17 \%$ & 83 & $100 \%$ \\
\hline & Lisans üstü & 1 & $11 \%$ & 3 & $33 \%$ & 1 & $11 \%$ & 4 & $44 \%$ & 9 & $100 \%$ \\
\hline \multicolumn{2}{|c|}{ Toplam } & 36 & $27 \%$ & 45 & $33 \%$ & 32 & $24 \%$ & 22 & $16 \%$ & 135 & $100 \%$ \\
\hline
\end{tabular}

Tablo 9'da eğitim durumları ve iş unvanları karşılaştırıldığında lise mezunlarının yarıdan fazlasını memurlar oluştururken lisansüstü eğitim yapanların yarıya yakınını da yöneticiler oluşturmaktadır.

Katılımcıların denetim alanında katıldıkları eğitim kursları veriler Tablo 12'de verilmiştir.

Tablo 10. Katılımcıların Denetim Alanında Katıldıkları Eğitim Kursları Sayısına İlişkin Veriler

\begin{tabular}{|c|c|c|}
\hline Katılınan Denetim Kursu Sayısı & Katılımcı sayısı & Yüzde \\
\hline Hiçbir kursa katılmayan & 32 & $\% 23,7$ \\
\hline Bir kursa katılan & 21 & $\% 15,6$ \\
\hline İki kursa katılan & 20 & $\% 14,8$ \\
\hline Üç kursa katılan & 14 & $\% 10,4$ \\
\hline
\end{tabular}




\begin{tabular}{|c|c|c|}
\hline Üçten fazla kursa katılan & 48 & $\% 35,6$ \\
\hline Toplam & 135 & $\% 100$ \\
\hline
\end{tabular}

Tablo 10' da da görüleceği üzere katılımcıların 32'si (\%23,7) hariç bugüne kadar denetim ile ilgili en az bir kursa katılmıştır. Bu da Irak Sünni Vakfı Divanı’nda çalışanların eğitimine verilen önemin bir göstergesidir. Bu veriler ayrıca çalışmanın denetim konusunda bilinçli bir katılımcı kitlesine uygulandı̆̆ııı da göstermektedir.

Denetim kurslarına katılan katılımcıların bölümler itibariyle verileri Tablo 11'de verilmiştir.

Tablo 11. Denetleme Kurslarına Katılan Katılımcılar ve Bölümlerine İlikin Veriler

\begin{tabular}{|c|c|c|c|c|}
\hline Kurs sayısı & Denetim Bölümü & Muhaseb Bölümü & Diğerleri & Yüzde \\
\hline Hiçbir kursa katılmayan & 4 & 27 & 1 & $\% 23,7$ \\
\hline Bir kursa katılan & 9 & 12 & 0 & $\% 15,6$ \\
\hline İki kursa katılan & 7 & 12 & 1 & $\% 14,8$ \\
\hline Üç kursa katılan & 9 & 4 & 1 & $\% 10,4$ \\
\hline Üçten fazla kursa katılan & 25 & 23 & 0 & $\% 35,6$ \\
\hline Toplam & 54 & 78 & 3 & $\% 100$ \\
\hline
\end{tabular}

Tablo 11'e göre denetim bölümü elemanları muhasebe bölümü elemanlarına göre daha fazla kursa katılmıştır. Denetim bölümünün görece bu üstünlüğü normaldir. Çünkü denetim alanında yaşanan gelişmelerin denetim bölümünde çalışanlara daha çok aktarılması gerekmektedir. Bu durum denetim bölümünün diğer bölümler üzerinde danışmanlık görevi olmasından da kaynaklanıyor olabilir. Aynı şekilde muhasebe bölümü elemanları da muhasebe ile ilgili gelişmeleri kurslar aracıllğ̆ ile takip etmekte ve kurslara katılım konusunda denetim bölümünden pek geriye kalmamaktadır.

\subsection{Hipotezlerin Test Edilmesi}

Bu başl1kta daha önce belirlenen 24 adet hipotez test edilecektir. Bu hipotezleri test etmek için öncelikle faktör analizi yapılmış ve çalışma faktörleri üzerine Mann-Whitney Test ve Kruskal-Wallis Testleri uygulanmıştır. Aşağıdaki tabloda, gerekli analizleri yapmak için örneğin yeterli olup olmadığı incelenmiştir.

Tablo 12. Çalışma Örneğinin Yeterliliği

\begin{tabular}{|c|c|c|}
\hline \multicolumn{3}{|c|}{ KMO and Bartlett's Test } \\
\hline Kaiser-Meyer-Olkin Measure of Sampling Adequacy. &, 889 \\
\hline \multirow{2}{*}{$\begin{array}{c}\text { Bartlett's Test of } \\
\text { Sphericity }\end{array}$} & Approx. Chi-Square & 2434,281 \\
\cline { 2 - 3 } & Df & 435 \\
\cline { 2 - 3 } & Sig. &, 000 \\
\hline
\end{tabular}

Tablo 12 'de, iç denetim ve iç kontrol ile ilgili sorulara yapılan faktör analizine başlamadan önce KMO 0,889 olarak bulunmuş olup Bertt'in spericity özelliği de sağlanmaktadır.

Aşağıdaki tabloda, çalışma faktör sayısı verilmiştir.

Tablo 13. Çalışma Faktör Sayısı

\begin{tabular}{|c|c|c|c|c|c|c|}
\hline \multicolumn{7}{|c|}{ Toplam Variance Explained } \\
\hline \multirow{2}{*}{ Faktörler } & \multirow{2}{*}{ Faktör İsimleri } & \multicolumn{3}{|c|}{ Initial Eigenvalues } & \multicolumn{2}{|c|}{$\begin{array}{l}\text { Extraction Sums of } \\
\text { Squared Loadings }\end{array}$} \\
\hline & & Toplam & $\begin{array}{c}\% \text { of } \\
\text { Variance }\end{array}$ & $\underset{\%}{\text { Cumulative }}$ & Toplam & $\%$ of Variance \\
\hline Faktör 1 & Bilgi ve İletişim & 11,202 & 37,341 & 37,341 & 11,202 & 37,341 \\
\hline Faktör 2 & Risk Değerlendirme & 2,640 & 8,800 & 46,141 & 2,640 & 8,800 \\
\hline Faktör 3 & Güvence Sağlama & 2,114 & 7,048 & 53,190 & 2,114 & 7,048 \\
\hline Faktör 4 & Bağımsızlık & 1,508 & 5,026 & 58,216 & 1,508 & 5,026 \\
\hline Faktör 5 & Kontrol Faaliyetleri & 1,269 & 4,230 & 62,446 & 1,269 & 4,230 \\
\hline Faktör 6 & Kontrol Ortamı & 1,029 & 3,430 & 65,876 & 1,029 & 3,430 \\
\hline
\end{tabular}


Tablo 13 'te de görüldüğü gibi, ön şartlar yerine geldiği için yapılan faktör analizi sonucunda öz değeri 1'den büyük olan toplam 6 faktör belirlenmiş ve bu faktörler toplam değişimin \% 65,876'sını açıklamaktadır.

Ortaya çıkan 6 faktörün 2 tanesi "faktör 3 güvence sağlama" ile "faktör 4 bağımsızlık" iç denetimin iki temel unsurunu ifade etmektedir. İç denetimin bu iki temel unsur dışında kurum kültürüne değer katmak ve geliştirmek, sistematik ve disiplinli bir yaklaşım olması gibi unsurları da bulunmaktadır. Ancak güvence sağlama ve bağımsızlık olmazsa olmaz iki unsurdur. Çalışmada da faktör olarak sayılan iki temel unsur ortaya çıkmıştır. Diğer 4 faktör ise iç kontrolün 4 unsurunu ifade etmektedir. Bunlar bilgi ve iletişim, risk değerlendirme, kontrol faaliyetleri ve kontrol ortamıdır. İç kontrolün "izleme" adında bir unsuru daha bulunmaktadır. Ancak izleme iç kontrolün diğer unsurları gibi değildir. Çünkü izleme aslında bir gözleme faaliyetidir. Bu faaliyet asıl işleri yapan birimlerden daha çok iç kontrol sürecini gözleyen ve aksaklıkları rapor eden iç denetim birimince yapılmaktadır. $\mathrm{O}$ nedenle bir faktör olarak ortaya çıkmaması olağan karşılanmıştır.

Belirlenen faktörler ve açıklamaları aşağıda verilmiştir:

a) Faktör 1 "Bilgi ve İletişim" toplam 8 soruyu içermektedir. Faktör 1 toplam değişim olan \% 65,876 'daki \% 37,34 ile en büyük paya sahiptir. Bilgi ve iletişim, iç kontrol unsurlarından birisidir. İç kontrol sisteminin etkin olabilmesi işletmedeki yatay ve dikey olarak bilgi temini ve örgüt içi iletişim etkinline bağlıdır (Bütçe ve Mali Kontrol Genel Müdürlüğü (BÜMKO), https://kontrol.bumko.gov.tr/Eklenti/3666, ustyonpdf.pdf, Son Erişim Tarihi: 01.11.2017)).

b) Faktör 2 "Risk değerlendirme " de 6 soru olup \% 8,8 oranında varyansı açıklama oranına sahiptir. Risk Değerlendirme, iç kontrol unsurlarından biridir. Risk değerlendirme, finansal raporlamanın belirlenen prosedürlere uygunluğunun sağlanması bakımından yönetimin belirlediği risk tanımları ve risk analizlerinden meydana gelir (Kardeş Selimoğlu vd., 2014:110).

c) Faktör 3 "Güvence Sağlama" 5 soru olup \% 7,05 oranında varyansı açıklama oranına sahiptir. Güvence sağlama iç denetimin unsurlarından birisidir. Güvence Sağlama, etkili denetim sistemlerinin varlığına, risk yönetimi, kontrol sistemleri ve süreçlerin verimli olarak çalıştığına, elde edilen bilgi ve bulguların doğru ve tam olduğuna, kurumun sahip olduğu varlıkların güvence altında olduğuna, belirlenen faaliyet ve eylemlerin etkin, ekonomik, gerekli mevzuatlara uygun ve verimli bir şekilde gerçekleşip gerçekleşmediğine ilişkin kurum içi ve kurum dış1 gerekli güvencenin verilmesi anlaş11ır (Moeller, 2009:5).

d) Faktör 4 "Bağımsızlık" 6 soru olup \% 5,03 oranında varyansı açıklama oranına sahiptir. Bağımsızlık iç denetim unsurlarından birisidir. Bağımsızlık, iç denetimler, herhangi bir işletmenin faaliyetleri ile farklı ve bağımsız olmalı, çalışmalarını bağımsız bir şekilde yapabilecek düzeyde yetkili kişilere bağl1 olarak ve görevlerini engellemeden yapabilmelidirler (Pickett, 2011:143).

e) Faktör 5 " Kontrol Faaliyetleri " 3 soru olup \% 4,23 oranında varyansı açıklama oranına sahiptir. Kontrol faaliyetleri, iç kontrol unsurlarından birisidir. Kontrol faaliyetleri, iç kontrolün somut olarak ifade edilebilen unsurunu oluşturmaktadır. Bu nedenle başlangıçta iç kontrol sadece kontrol faaliyetleriyle eş anlamlı olarak düşünülmüştür. Bu faaliyetleri işletmelerin hedeflerine ulaşmalarını engelleme ihtimali olan risklerin önüne geçilmesinde yardım eden politika ve yöntemlerin uygulanmasinı kapsar (Y1lanc1 vd., 2012:80).

f) Faktör 6 " Kontrol Ortamı " 2 soru olup \% 3,43 varyans açıklama oranına sahiptir. Kontrol ortamı, iç kontrol unsurlarından birisidir. Kontrol ortamı, bir işlem grubu için oluşturulan yöntem ve politikaların, etkinliklerinin arttırılmasında ya da azaltılmasında olan faktörleri kapsamaktadır (Erkan, 2000:73).

Her bir faktöre ait sorular ve yükleri tablo 14 ’te verilmiştir. 
Tablo 14. Faktörlere Ait Sorular ve Yükleri

\begin{tabular}{|c|c|c|c|c|c|c|c|}
\hline \multicolumn{7}{|l|}{ Rotated Component Matrix ${ }^{a}$} & \\
\hline \multirow[b]{2}{*}{ Sorular } & \multicolumn{6}{|c|}{ Faktörler } & \multirow[b]{2}{*}{ Extraction } \\
\hline & 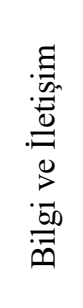 & 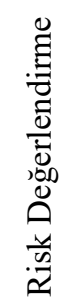 & 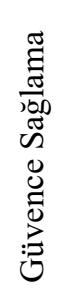 & 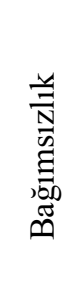 & 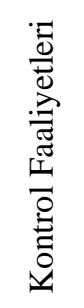 & 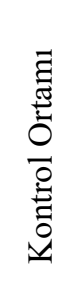 & \\
\hline $\begin{array}{l}\text { 1.Sünni Vakfi Divanı, performans etkinliğini sağlamaya } \\
\text { katkıda bulunur. }\end{array}$ & & & & & &, 592 & ,662 \\
\hline $\begin{array}{l}\text { 2.Sünni Vakfı Divanı yönetiminin politikaları verimlilik } \\
\text { gerçekleştirilmesine katkıda bulunur }\end{array}$ & & & & & &, 730 & ,717 \\
\hline $\begin{array}{l}\text { 3.Sünni Vakfı Divanı çalışanlarının tüm görev ve } \\
\text { sorumlulukları açık ve anlaşılabilirdir. }\end{array}$ & ,673 & & & & & & ,615 \\
\hline $\begin{array}{l}\text { 4.Sünni Vakfı Divanı Birimleri, faaliyetleri ile ilgili karar } \\
\text { alırken uydukları yardımcı bir dizi kriterleri vardır. }\end{array}$ & 654 & & & & & & ,628 \\
\hline $\begin{array}{l}\text { 5.Sünni vakfi Divanı, kurumsal değerlere uymanın tüm } \\
\text { şartlarını desteklemektedir. }\end{array}$ & ,626 & & & & & & 678 \\
\hline $\begin{array}{l}\text { 6.İç Denetim Bölümü sunulan denetim raporları, denetim } \\
\text { süreçlerinin başarısına katkıda bulunur. }\end{array}$ & & & &, 559 & & & ,694 \\
\hline $\begin{array}{l}\text { 7.Yetkilerin çeşitli idari seviyelerde dağılımı, düzenleyici } \\
\text { prosedürlerin iyileştirilmesine katkıda bulunur. }\end{array}$ & & & &, 595 & & & ,665 \\
\hline $\begin{array}{l}\text { 8.Bölümlerdeki, kontrol faaliyetleri, varlık ve kayıtlar için } \\
\text { kontrol politikalarını içerir. }\end{array}$ & & & & &, 501 & &, 565 \\
\hline $\begin{array}{l}\text { 9. Yönetime sunulan raporlar, farklı performans } \\
\text { dönemlerinin sonuçlarının periyodik olarak } \\
\text { karşılaştırılmasını sağlar. }\end{array}$ & & & & & ,792 & &, 724 \\
\hline $\begin{array}{l}\text { 10.Yönetim ile ilgili gözetim raporları, performansı ele } \\
\text { almak ve değerlendirmek için öneriler içerir. }\end{array}$ & & & & &, 729 & & ,640 \\
\hline $\begin{array}{l}\text { 11.İç Denetim Bölümü maruz kalabileceği tüm riskleri } \\
\text { değerlendiren mekanizmalar oluşturmaktadır. }\end{array}$ & & ,670 & & & & & ,619 \\
\hline $\begin{array}{l}\text { 12.İç Denetim Bölümü hangi risklerin kontrol } \\
\text { edilebileceğini ve kontrol edilemeyeceğini } \\
\text { belirlemektedir. }\end{array}$ & &, 748 & & & & &, 761 \\
\hline $\begin{array}{l}\text { 13.İç Denetim Bölümü, tüm riskleri, faaliyet üzerindeki } \\
\text { etki düzeyleri açısından sinıflandırır. }\end{array}$ & &, 757 & & & & &, 721 \\
\hline $\begin{array}{l}\text { 14.Riskler, İç Denetim Bölümü tarafından sürekli olarak } \\
\text { değerlendirilir. }\end{array}$ & &, 801 & & & & & ,706 \\
\hline $\begin{array}{l}\text { 15.İç Denetim Bölümü, riskleri değerlendirirken maliyet } \\
\text { ve fayda ilkesini dikkate alır. }\end{array}$ & & 817 & & & & & ,716 \\
\hline $\begin{array}{l}\text { 16.Bölümler tarafından kullanılan finansal bilgi sistemi } \\
\text { sık1 ve doğrudur. }\end{array}$ & 623 & & & & & & ,634 \\
\hline $\begin{array}{l}\text { 17.Sünni vakfı Divanı, tüm idari seviyelere bilgi sunmak } \\
\text { için uygun bir bilgi ve iletişim sistemine sahiptir. }\end{array}$ & ,634 & & & & & & 620 \\
\hline $\begin{array}{l}\text { 18.Bilgi Sistemleri, İç Denetim Bölümünün düzenleyici } \\
\text { prosedürlerinin iyileştirilmesine katkıda bulunan doğru } \\
\text { bilgileri sağlar. }\end{array}$ &, 540 & & & & & &, 526 \\
\hline $\begin{array}{l}\text { 19.Çalışanların tüm yetkilerine ve sorumluluklarına açıklık } \\
\text { getiren bir iletişim sisteminin varlığı söz konusudur. }\end{array}$ &, 730 & & & & & & 639 \\
\hline $\begin{array}{l}\text { 20.İletişim kanalları, tüm çalışanların kontrol ile ilgili } \\
\text { politikaları ve prosedürleri anlamalarını sağlar. }\end{array}$ & 697 & & & & & &, 593 \\
\hline $\begin{array}{l}\text { 21.İç Denetçinin bağımsızlığı, iç denetim bölümünün } \\
\text { organizasyon yapısındaki konumuna büyük ölçüde } \\
\text { bağlıdır. }\end{array}$ & & & &, 740 & & & ,654 \\
\hline $\begin{array}{l}\text { 22.İç Denetim Bölümü üst düzey yönetim ile doğrudan } \\
\text { iletisim hattına sahiptir. }\end{array}$ & & & & ,615 & & & ,549 \\
\hline
\end{tabular}




\begin{tabular}{|c|c|c|c|c|}
\hline $\begin{array}{l}\text { 23.İç Denetim Bölümü, Sünni Vakfı Divanı amaçlarına } \\
\text { ulaşılmasına katkıda bulunur. }\end{array}$ & & & ,597 & 669, \\
\hline $\begin{array}{l}\text { 24.İç Denetim Bölümü kararlarını herhangi bir bask1 } \\
\text { altında kalmadan verebilmektedir. }\end{array}$ & & &, 550 & ,672 \\
\hline $\begin{array}{l}\text { 25.İç Denetim Bölümü, gözden geçirdiği faaliyetlerde } \\
\text { bağımsızlığını korumaktadır. }\end{array}$ & ,533 & & & ,607 \\
\hline $\begin{array}{l}\text { 26.İç Denetim Bölümü üyeleri, görevlerini etkili bir } \\
\text { şekilde yerine getirebilmeleri için yeterli tecrübeye } \\
\text { sahiptir. }\end{array}$ & & 640 & & ,720 \\
\hline $\begin{array}{l}\text { 27.İç Denetim Bölümü üyelerinin birbirinden farklı } \\
\text { denetleme becerileri vardır. }\end{array}$ & &, 570 & & 649 \\
\hline $\begin{array}{l}\text { 28.İç Denetim Bölümü üyeleri muhasebe/finans alanında } \\
\text { üniversite lisans derecesine sahiptir. }\end{array}$ & & ,732 & & ,635 \\
\hline $\begin{array}{l}\text { 29. İçDenetim Bölümü üyelerinin deneyimi, onlara } \\
\text { denetim sürecinde yeterli bilgi sağlar. }\end{array}$ & & ,727 & & ,761 \\
\hline $\begin{array}{l}\text { 30.İç Denetim Bölümü üyeleri muhasebe konusunda } \\
\text { yeterlidirler. }\end{array}$ & & ,774 & & ,727 \\
\hline
\end{tabular}

Tablo 14'te, genel olarak değişkenlerin verilen faktörler ile en yüksek ortalama farkları gösterilmektedir. Genel olarak çalışmamızda bu veriler üzerinde durularak değişkenler arasında farkın olup olmaması belirlenerek istatiksel veri olarak tablolarda verilecektir. Tabloda genel olarak en yüksek ortalamaya sahip olan risk değerlendirmesi görülmektedir. Bu da araştırmamızda istatiksel olarak bu değişkenler arasında anlamlı bir farkın olduğu belirlenmiştir.

\subsection{HA1-HA2 Hipotezlerin Test Edilmesi}

Yapılan literatür taraması sonucunda belirlenen hipotezlerden 1., 2., 3., 4., 5. ve 6. hipotezler aşağıdaki gibiydi:

HA1. İç kontrol unsurlarından bilgi ve iletişim unsuru ile çalışanın eğitim durumu arasında istatistik olarak anlamlı bir ilişki vardır.

HA2. İç kontrol unsurlarından risk değerlendirme unsuru ile çalışanın eğitim durumu arasında istatistik olarak anlamlı bir ilişki vardır.

HA3. İç denetim unsurlarından güvence sağlama unsuru ile çalışanın eğitim durumu arasında istatistik olarak anlamlı bir ilişki vardır.

HA4. İç denetim unsurlarından bağımsızlık unsuru ile çalışanın eğitim durumu arasında istatistik olarak anlamlı bir ilişki vardır.

HA5. İç kontrol unsurlarından kontrol faaliyetleri unsuru ile çalışanın eğitim durumu arasında istatistik olarak anlamlı bir ilişki vardır.

HA6. İç kontrol unsurlarından kontrol ortamı unsuru ile çalışanın eğitim durumu arasında istatistik olarak anlamlı bir ilişki vardır.

$\mathrm{Bu} 6$ hipotezin test edilebilmesi için genel olarak Kruskal-Walliss testi yapılarak faktörlerle çalışanların eğitimleri arasındaki anlamlı ilişkilerin olup olmadığı belirlenmiştir. Katılımcıların eğitim durumu ile faktörler arasındaki ilişki Tablo 15 'te sunulmuş ve verilerin sonuçları yorumlanarak tabloların alt kısmında verilmiştir.

Tablo 15. Katılımcıların Eğitim Durumu ile Faktörler Arasındaki İlişki

\begin{tabular}{|c|c|c|c|c|c|c|}
\hline \multicolumn{4}{|c|}{ Ranks } & \multicolumn{3}{|c|}{ Test Statistics $^{\mathbf{a}, \mathrm{b}}$} \\
\hline & eğitim & $\begin{array}{c}\text { Katılıme } \\
\text { sayısı }\end{array}$ & Mean Rank & $\begin{array}{l}\text { Chi- } \\
\text { Square }\end{array}$ & df & $\begin{array}{l}\text { Asymp. } \\
\text { Sig. }\end{array}$ \\
\hline \multirow{5}{*}{$\begin{array}{c}\text { Faktör } 1 \\
\text { Bilgi ve İletişim }\end{array}$} & Lise & 22 & 72,55 & \multirow{5}{*}{1,435} & \multirow{5}{*}{3} & \multirow{5}{*}{0,697} \\
\hline & Ön lisans & 21 & 72,33 & & & \\
\hline & Lisans & 83 & 64,87 & & & \\
\hline & Lisans üstü & 9 & 75,61 & & & \\
\hline & Toplam & 135 & & & & \\
\hline \multirow{2}{*}{$\begin{array}{c}\text { Faktör } 2 \\
\text { Risk Değerlendirme }\end{array}$} & Lise & 22 & 78 & \multirow{2}{*}{1,904} & \multirow{2}{*}{3} & \multirow{2}{*}{0,593} \\
\hline & Ön lisans & 21 & 69,12 & & & \\
\hline
\end{tabular}




\begin{tabular}{|c|c|c|c|c|c|c|}
\hline & Lisans & 83 & 65,48 & & & \\
\hline & Lisans üstü & 9 & 64,17 & & & \\
\hline & Toplam & 135 & & & & \\
\hline \multirow{5}{*}{$\begin{array}{c}\text { Faktör } 3 \\
\text { Güvence Sağlama }\end{array}$} & Lise & 22 & 81,45 & \multirow{5}{*}{6,100} & \multirow{5}{*}{3} & \multirow{5}{*}{0,107} \\
\hline & Ön lisans & 21 & 77 & & & \\
\hline & Lisans & 83 & 61,66 & & & \\
\hline & Lisans üstü & 9 & 72,56 & & & \\
\hline & Toplam & 135 & & & & \\
\hline \multirow{5}{*}{$\begin{array}{c}\text { Faktör } 4 \\
\text { Bağımsızlık }\end{array}$} & Lise & 22 & 64,59 & \multirow{5}{*}{4,227} & \multirow{5}{*}{3} & \multirow{5}{*}{0,238} \\
\hline & Ön lisans & 21 & 62,79 & & & \\
\hline & Lisans & 83 & 67,54 & & & \\
\hline & Lisans üstü & 9 & 92,78 & & & \\
\hline & Toplam & 135 & & & & \\
\hline \multirow{5}{*}{$\begin{array}{c}\text { Faktör } 5 \\
\text { Kontrol Faaliyetleri }\end{array}$} & Lise & 22 & 64,43 & \multirow{5}{*}{1,704} & \multirow{5}{*}{3} & \multirow{5}{*}{0,636} \\
\hline & Ön lisans & 21 & 63,9 & & & \\
\hline & Lisans & 83 & 68,47 & & & \\
\hline & Lisans üstü & 9 & 81,94 & & & \\
\hline & Toplam & 135 & & & & \\
\hline \multirow{5}{*}{$\begin{array}{c}\text { Faktör } 6 \\
\text { Kontrol Ortamı }\end{array}$} & Lise & 22 & 67,77 & \multirow{5}{*}{5,189} & \multirow{5}{*}{3} & \multirow{5}{*}{0,158} \\
\hline & Ön lisans & 21 & 65,64 & & & \\
\hline & Lisans & 83 & 65,68 & & & \\
\hline & Lisans üstü & 9 & 95,44 & & & \\
\hline & Toplam & 135 & & & & \\
\hline
\end{tabular}

Tablo 15'te, sig değerlerin 0.05 den büyük olması bu değişkenler arasında hiçbir anlamlı ilişki olmadığını göstermektedir. Anlamlı farkın olmadı ̆̆ı, aşağıdaki verilerin çıktısında daha belirgin olarak kesinleştirilmiştir:

a. Faktör 1 (Bilgi ve İletişim) bakımından elde edilen verilere yapılan Kruskal-Walliss testi sonucunda eğitim seviyelerinin Rank ortalamaları arasındaki farklar istatistik olarak önemli değildir. $(\mathrm{P}<0,05)$ Dolayısıyla 1. hipotez reddedilmiştir.

b. Faktör 2 (Risk Değerlendirme) bakımından elde edilen verilere yapılan Kruskal-Walliss testi sonucunda eğitim seviyelerinin Rank ortalamaları arasındaki farklar istatistik olarak önemli değildir. $(\mathrm{P}<0,05)$ Dolayısıyla 2. hipotez reddedilmiştir.

c. Faktör 3 (Güvence Sağlama) bakımından elde edilen verilere yapılan Kruskal-Walliss testi sonucunda eğitim seviyelerinin Rank ortalamaları arasındaki farklar istatistik olarak önemli değildir. $(\mathrm{P}<0,05)$ Dolayısıyla 3. hipotez reddedilmiştir.

d. Faktör 4 (Bağımsızlık) bakımından elde edilen verilere yapılan Kruskal-Walliss testi sonucunda eğitim seviyelerinin Rank ortalamaları arasındaki farklar istatistik olarak önemli değildir. $(\mathrm{P}<0,05)$ Dolayısıyla 4. hipotez reddedilmiştir.

e. Faktör 5 (Kontrol Faaliyetleri) bakımından elde edilen verilere yapılan Kruskal-Walliss testi sonucunda eğitim seviyelerinin Rank ortalamaları arasındaki farklar istatistik olarak önemli değildir. $(\mathrm{P}<0,05)$ Dolayısıyla 5. hipotez reddedilmiştir.

f. Faktör 6 (Kontrol Ortamı) bakımından elde edilen verilere yapılan Kruskal-Walliss testi sonucunda eğitim seviyelerinin Rank ortalamaları arasındaki farklar istatistik olarak önemli değildir. $(\mathrm{P}<0,05)$ Dolayısıyla 6 . hipotez reddedilmiştir.

\subsection{HA7-HA12 Hipotezlerin Test Edilmesi}

Yapılan literatür taraması sonucunda belirlenen hipotezlerden 7., 8., 9., 10., 11. ve 12. hipotezler aşağıdaki gibiydi: 
HA7. İç kontrol unsurlarından bilgi ve iletişim unsuru ile çalışanın deneyim yllı arasında istatistik olarak anlamlı bir ilişki vardır.

HA8. İç kontrol unsurlarından risk değerlendirme unsuru ile çalışanın deneyim yılı arasında istatistik olarak anlamlı bir ilişki vardır.

HA9. İç denetim unsurlarından güvence sağlama unsuru ile çalışanın deneyim yılı arasında istatistik olarak anlamlı bir ilişki vardır.

HA10. İç denetim unsurlarından bağımsızlık unsuru ile çalışanın deneyim yılı arasında istatistik olarak anlamlı bir ilişki vardır.

HA11. İç kontrol unsurlarından kontrol faaliyetleri unsuru ile çalışanın deneyim yılı arasında istatistik olarak anlamlı bir ilişki vardır.

HA12. İç kontrol unsurlarından kontrol ortamı unsuru ile çalışanın deneyim yılı arasında istatistik olarak anlamlı bir ilișki vardır.

Aşağıdaki tabloda genel olarak Kruskal-Walliss testi yapılarak faktörlerle çalışanların deneyim yılları arasındaki anlamlı ilişkilerin olup olmadığı belirlenmiştir. Genel olarak verilerin sonuçları yorumlanarak tabloların alt kısmında verilmiştir.

Tablo 16. Deneyim Yılı ile Faktörler Arasındaki İlişski

\begin{tabular}{|c|c|c|c|c|c|c|}
\hline \multicolumn{4}{|c|}{ Ranks } & \multicolumn{3}{|c|}{ Test Statistics $^{\mathrm{a}, \mathrm{b}}$} \\
\hline & Deneyim yılı & $\begin{array}{l}\text { Katılım } \\
\text { cl sayısı }\end{array}$ & $\begin{array}{l}\text { Mean } \\
\text { Rank }\end{array}$ & $\begin{array}{c}\text { Chi- } \\
\text { Square }\end{array}$ & df & $\begin{array}{l}\text { Asymp. } \\
\text { Sig. }\end{array}$ \\
\hline \multirow{5}{*}{$\begin{array}{c}\text { Faktör } 1 \\
\text { Bilgi ve İletişim }\end{array}$} & 5 yıl ya da daha az & 42 & 68,83 & \multirow{5}{*}{2,273} & \multirow{5}{*}{3} & \multirow{5}{*}{0,518} \\
\hline & 6-10 yil arasinda & 48 & 67,92 & & & \\
\hline & 11-15 y1l arasında & 28 & 74,09 & & & \\
\hline & 16 yil ve üzeri & 17 & 56,15 & & & \\
\hline & Toplam & 135 & & & & \\
\hline \multirow{5}{*}{$\begin{array}{c}\text { Faktör } 2 \\
\text { Risk Değerlendirme }\end{array}$} & 5 y1l ya da daha az & 42 & 77,3 & \multirow{5}{*}{5,212} & \multirow{5}{*}{3} & \multirow{5}{*}{0,157} \\
\hline & 6-10 yil arasında & 48 & 67,83 & & & \\
\hline & 11-15 yil arasında & 28 & 55,8 & & & \\
\hline & 16 yıl ve üzeri & 17 & 65,59 & & & \\
\hline & Toplam & 135 & & & & \\
\hline \multirow{5}{*}{$\begin{array}{c}\text { Faktör } 3 \\
\text { Güvence Sağlama }\end{array}$} & 5 yıl ya da daha az & 42 & 72,64 & \multirow{5}{*}{3,292} & \multirow{5}{*}{3} & \multirow{5}{*}{0,349} \\
\hline & 6-10 y1l arasında & 48 & 71,97 & & & \\
\hline & 11-15 y1l arasında & 28 & 59,63 & & & \\
\hline & 16 yıl ve üzeri & 17 & 59,12 & & & \\
\hline & Toplam & 135 & & & & \\
\hline \multirow{5}{*}{$\begin{array}{c}\text { Faktör } 4 \\
\text { Bağımsızıı }\end{array}$} & 5 y1l ya da daha az & 42 & 73,93 & \multirow{5}{*}{3,154} & \multirow{5}{*}{3} & \multirow{5}{*}{0,368} \\
\hline & 6-10 yıl arasında & 48 & 65,59 & & & \\
\hline & 11-15 yil arasinda & 28 & 59,11 & & & \\
\hline & 16 yıl ve üzeri & 17 & 74,79 & & & \\
\hline & Toplam & 135 & & & & \\
\hline \multirow{5}{*}{$\begin{array}{c}\text { Faktör } 5 \\
\text { Kontrol Faaliyetleri }\end{array}$} & 5 yıl ya da daha az & 42 & 67,31 & \multirow{5}{*}{0,295} & \multirow{5}{*}{3} & \multirow{5}{*}{0,961} \\
\hline & 6-10 yil arasında & 48 & 67,26 & & & \\
\hline & 11-15 yil arasında & 28 & 67,5 & & & \\
\hline & 16 yıl ve üzeri & 17 & 72,62 & & & \\
\hline & Toplam & 135 & & & & \\
\hline \multirow{5}{*}{$\begin{array}{c}\text { Faktör } 6 \\
\text { Kontrol Ortamı }\end{array}$} & 5 y1l ya da daha az & 42 & 66,69 & \multirow{5}{*}{4,765} & \multirow{5}{*}{3} & \multirow{5}{*}{0,190} \\
\hline & 6-10 yıl arasında & 48 & 66,98 & & & \\
\hline & 11-15 yil arasında & 28 & 79,59 & & & \\
\hline & 16 yıl ve üzeri & 17 & 55,03 & & & \\
\hline & Toplam & 135 & & & & \\
\hline
\end{tabular}

Tablo 16'da, sig değerlerin 0.05 den büyük olması bu değişkenler arasında hiçbir anlamlı ilişki olmadığını göstermektedir. Anlamlı farkın olmadığı aşağıdaki verilerin çıktısında daha belirgin olarak kesinleştirilmiştir:

a. Faktör 1 (Bilgi ve İletişim) bakımından elde edilen verilere yapılan Kruskal-Walliss testi sonucunda deneyim y1lı seviyelerinin Rank ortalamaları arasındaki farklar istatistik olarak önemli değildir. $(\mathrm{P}<0,05)$ Dolayısıyla 7 . hipotez reddedilmiştir. 
b. Faktör 2 (Risk Değerlendirme) bakımından elde edilen verilere yapılan Kruskal-Walliss testi sonucunda deneyim yılı seviyelerinin Rank ortalamaları arasındaki farklar istatistik olarak önemli değildir. $(\mathrm{P}<0,05)$ Dolayısıyla 8. hipotez reddedilmiştir.

c. Faktör 3 (Güvence Sağlama) bakımından elde edilen verilere yapılan Kruskal-Walliss testi sonucunda deneyim yılı seviyelerinin Rank ortalamaları arasındaki farklar istatistik olarak önemli değildir. $(\mathrm{P}<0,05)$ Dolayısıyla 9. hipotez reddedilmiştir.

d. Faktör 4 (Bağımsızlık ) bakımından elde edilen verilere yapılan Kruskal-Walliss testi sonucunda deneyim yılı seviyelerinin Rank ortalamaları arasındaki farklar istatistik olarak önemli değildir. $(\mathrm{P}<0,05)$ Dolayısıyla 10. hipotez reddedilmiştir.

e. Faktör 5 (Kontrol Faaliyetleri) bakımından elde edilen verilere yapılan Kruskal-Walliss testi sonucunda deneyim yılı seviyelerinin Rank ortalamaları arasındaki farklar istatistik olarak önemli değildir. $(\mathrm{P}<0,05)$ Dolayısıyla 11. hipotez reddedilmiştir.

f. Faktör 6 (Kontrol Ortamı) bakımından elde edilen verilere yapılan Kruskal-Walliss testi sonucunda deneyim yılı seviyelerinin Rank ortalamaları arasındaki farklar istatistik olarak önemli değildir. $(\mathrm{P}<0,05)$ Dolayısıyla 12. hipotez reddedilmiştir.

\subsection{HA13-HA18 Hipotezlerin Test Edilmesi}

Yapılan literatür taramas1 sonucunda belirlenen hipoteslerden 13., 14., 15., 16., 17. Ve 18. Hipotezler aşağıdaki gibiydi:

HA13. İç kontrol unsurlarından bilgi ve iletişim unsuru ile çalışanın iş ünvanı arasında istatistik olarak anlamlı bir ilişki vardır.

HA14. İç kontrol unsurlarından risk değerlendirme unsuru ile çalışanın iş ünvanı arasında istatistik olarak anlamlı bir ilişki vardır.

HA15. İç denetim unsurlarından güvence sağlama unsuru ile çalışanın iş ünvanı arasında istatistik olarak anlamlı bir ilişki vardır.

HA16. İç denetim unsurlarından bağımsızlık unsuru ile çalışanın iş ünvanı arasında istatistik olarak anlamlı bir ilişki vardır.

HA17. İç kontrol unsurlarından kontrol faaliyetleri unsuru ile çalışanın iş ünvanı arasında istatistik olarak anlamlı bir ilişki vardır.

HA18. İç kontrol unsurlarından kontrol ortamı unsuru ile çalışanın iş ünvanı arasında istatistik olarak anlamlı bir ilişki vardır.

Aşağıdaki tabloda genel olarak Kruskal-Walliss testi yapılarak faktörlerle çalışanların iş ünvanı arasındaki anlamlı ilişkilerin olup olmadığı belirlenmiştir. Genel olarak verilerin sonuçları yorumlanarak tabloların alt kısmında verilmiştir.

Tablo 17. İş Ünvanı ile Faktörler Arasındaki İlişki

\begin{tabular}{|c|c|c|c|c|c|c|}
\hline \multicolumn{2}{|c|}{ Ranks } & \multicolumn{5}{|c|}{ Test Statisticsa, b } \\
\hline & İş Ünvanı & $\begin{array}{c}\text { Katılımeı } \\
\text { sayısı }\end{array}$ & $\begin{array}{l}\text { Mean } \\
\text { Rank }\end{array}$ & $\begin{array}{l}\text { Chi- } \\
\text { Square }\end{array}$ & df & $\begin{array}{l}\text { Asymp. } \\
\text { Sig. }\end{array}$ \\
\hline \multirow{5}{*}{$\begin{array}{c}\text { Faktör } 1 \\
\text { Bilgi ve İletişim }\end{array}$} & Memurlar & 36 & 76.93 & \multirow{5}{*}{3,566} & \multirow{5}{*}{3} & \multirow{5}{*}{0,312} \\
\hline & Muhasebeci & 45 & 64.10 & & & \\
\hline & Muhasebe Denetçisi & 32 & 60.97 & & & \\
\hline & Yönetici & 22 & 71.59 & & & \\
\hline & Toplam & 135 & & & & \\
\hline \multirow{5}{*}{$\begin{array}{c}\text { Faktör } 2 \\
\text { Risk Değerlendirme }\end{array}$} & Memurlar & 36 & $86,936 \mathrm{~A}$ & \multirow{5}{*}{12,542} & \multirow{5}{*}{3} & \multirow{5}{*}{0,06} \\
\hline & Muhasebeci & 45 & $64,567 \mathrm{~B}$ & & & \\
\hline & Muhasebe Denetçisi & 32 & $55,9062 \mathrm{~B}$ & & & \\
\hline & Yönetici & 22 & $61,3636 \mathrm{~B}$ & & & \\
\hline & Toplam & 135 & & & & \\
\hline Faktör 3 & Memurlar & 36 & 79.74 & 4,798 & 3 & 0,187 \\
\hline
\end{tabular}




\begin{tabular}{|c|c|c|c|c|c|c|}
\hline \multirow[t]{4}{*}{ Güvence Sağlama } & Muhasebeci & 45 & 62.50 & & & \\
\hline & Muhasebe Denetçisi & 32 & 66.88 & & & \\
\hline & Yönetici & 22 & 61.68 & & & \\
\hline & Toplam & 135 & & & & \\
\hline \multirow{5}{*}{$\begin{array}{r}\text { Faktör } 4 \\
\text { Bağımsızlık }\end{array}$} & Memurlar & 36 & 74.88 & \multirow{5}{*}{3,366} & \multirow{5}{*}{3} & \multirow{5}{*}{0,339} \\
\hline & Muhasebeci & 45 & 63.82 & & & \\
\hline & Muhasebe Denetçisi & 32 & 61.23 & & & \\
\hline & Yönetici & 22 & 75.14 & & & \\
\hline & Toplam & 135 & & & & \\
\hline \multirow{5}{*}{$\begin{array}{c}\text { Faktör } 5 \\
\text { Kontrol Faaliyetleri }\end{array}$} & Memurlar & 36 & 75.81 & \multirow{5}{*}{4,995} & \multirow{5}{*}{3} & \multirow{5}{*}{0,172} \\
\hline & Muhasebeci & 45 & 59.84 & & & \\
\hline & Muhasebe Denetçisi & 32 & 64.92 & & & \\
\hline & Yönetici & 22 & 76.39 & & & \\
\hline & Toplam & 135 & & & & \\
\hline \multirow{5}{*}{$\begin{array}{c}\text { Faktör } 6 \\
\text { Kontrol Ortamı }\end{array}$} & Memurlar & 36 & 68.01 & \multirow{5}{*}{0,581} & \multirow{5}{*}{3} & \multirow{5}{*}{0,901} \\
\hline & Muhasebeci & 45 & 71.01 & & & \\
\hline & Muhasebe Denetçisi & 32 & 66.44 & & & \\
\hline & Yönetici & 22 & 64.09 & & & \\
\hline & Toplam & 135 & & & & \\
\hline
\end{tabular}

Tablo 17'de, verilen sig değerlere baktığımızda ikinci faktör olan Risk Değerlendirme ile İş ünvanı ortalamaları arasındaki farkın olduğu sig değerlerin , $040<0.05$ den küçük olduğundan anlamlı farkın olduğu belirlenmiştir. Bu da aşağıdaki istatiksel verilerin çıktısına neden olmuştur:

a. Faktör 1 (Bilgi ve İletişim) bakımından elde edilen verilere yapılan Kruskal-Walliss testi sonucunda iş ünvanı Rank ortalamaları arasındaki farklar istatistik olarak önemli değildir. $(\mathrm{P}<0,05)$ Dolayısıyla 13. hipotez reddedilmiştir.

b. Faktör 2 (Risk Değerlendirme) bakımından elde edilen verilere yapılan Kruskal-Walliss testi sonucunda iş ünvanı Rank ortalmaları arasındaki farklar istatistik olarak önemlidir. $(\mathrm{P}<0,05)$ Dolayısıyla 14. hipotez kabul edilmiştir. Yapılan Bonferroni-Dunn testi sonuçları tablo 18'de Rank ortalamaları üzerinde Latin harfleri ile gösterilmiştir. En yüksek puanları memur ve muhasebeci iş ünvanı verirken en düşük puanları muhasebe denetçisi ve yönetici iş ünvanı verdiği görülmektedir.

c. Faktör 3 (Güvence Sağlama) bakımından elde edilen verilere yapılan Kruskal-Walliss testi sonucunda iş ünvanı Rank ortalamaları arasındaki farklar istatistik olarak önemli değildir. $(\mathrm{P}<0,05)$ Dolayısıyla 15. hipotez reddedilmiştir.

d. Faktör 4 (Bağımsızlık ) bakımından elde edilen verilere yapılan Kruskal-Walliss testi sonucunda iş ünvanı Rank ortalamaları arasındaki farklar istatistik olarak önemli değildir. $(\mathrm{P}<0,05)$ Dolayısıyla 16. hipotez reddedilmiştir.

e. Faktör 5 (Kontrol Faaliyetleri) bakımından elde edilen verilere yapılan Kruskal-Walliss testi sonucunda iş ünvanı Rank ortalamaları arasındaki farklar istatistik olarak önemli değildir. $(\mathrm{P}<0,05)$ Dolayısıyla 17. hipotez reddedilmiştir.

f. Faktör 6 (Kontrol Ortamı) bakımından elde edilen verilere yapılan Kruskal-Walliss testi sonucunda iş ünvanı Rank ortalamaları arasındaki farklar istatistik olarak önemli değildir. $(\mathrm{P}<0,05)$ Dolayısıyla 18. hipotez reddedilmiştir.

\subsection{HA19-HA24 Hipotezlerin Test Edilmesi}

Yapılan literatür taramas1 sonucunda belirlenen hipoteslerden 19., 20., 21., 22., 23. Ve 24. Hipotezler aşağıdaki gibiydi:

HA19. İç kontrol unsurlarından bilgi ve iletişim unsuru ile çalışanın aldığı kurs sayısı arasında istatistik olarak anlamlı bir ilişki vardır. 
HA20. İç kontrol unsurlarından risk değerlendirme unsuru ile çalışanın aldığı kurs sayısı arasında istatistik olarak anlamlı bir ilişki vardır.

HA21. İç denetim unsurlarından güvence sağlama unsuru ile çalışanın aldığı kurs sayısı arasında istatistik olarak anlamlı bir ilişki vardır.

HA22. İç denetim unsurlarından bağımsızlık unsuru ile çalışanın aldığı kurs sayısı arasında istatistik olarak anlamlı bir ilișki vardır.

HA23. İç kontrol unsurlarından kontrol faaliyetleri unsuru ile çalışanın aldığı kurs sayısı arasında istatistik olarak anlamlı bir ilişki vardır.

HA24. İç kontrol unsurlarından kontrol ortamı unsuru ile çalışanın aldığı kurs sayısı arasında istatistik olarak anlamlı bir ilişki vardır.

Aşağıdaki tabloda genel olarak Kruskal-Walliss testi yapılarak faktörlerle çalışanların denetim alanında eğitim kursları arasındaki anlamlı ilişkilerin olup olmadığı belirlenmiştir. Genel olarak verilerin sonuçları yorumlanarak tabloların alt kısmında verilmiştir.

Tablo 18. Denetim Alanında Eğitim Kursları İle Faktörler Arasındaki İliş̧ki

\begin{tabular}{|c|c|c|c|c|c|c|}
\hline \multicolumn{4}{|c|}{ Ranks } & \multicolumn{3}{|c|}{ Test Statistics ${ }^{\mathrm{a}, \mathrm{b}}$} \\
\hline & $\begin{array}{c}\text { Denetim } \\
\text { Alanında Eğitim } \\
\text { Kursları } \\
\end{array}$ & $\begin{array}{c}\text { Katılımeı } \\
\text { sayısı }\end{array}$ & $\begin{array}{l}\text { Mean } \\
\text { Rank }\end{array}$ & $\begin{array}{l}\text { Chi- } \\
\text { Square }\end{array}$ & df & $\begin{array}{l}\text { Asymp. } \\
\text { Sig. }\end{array}$ \\
\hline \multirow{6}{*}{$\begin{array}{c}\text { Faktör } 1 \\
\text { Bilgi ve İletişim }\end{array}$} & Hiçbir kursa & 32 & 66,48 & \multirow{6}{*}{1,565} & \multirow{6}{*}{4} & \multirow{6}{*}{0,815} \\
\hline & Bir kursa & 21 & 65,62 & & & \\
\hline & İki kursa & 20 & 77,73 & & & \\
\hline & Üç kursa & 14 & 63,61 & & & \\
\hline & Üçten fazla kursa & 48 & 67,28 & & & \\
\hline & Toplam & 135 & & & & \\
\hline \multirow{6}{*}{$\begin{array}{c}\text { Faktör } 2 \\
\text { Risk Değerlendirme }\end{array}$} & Hiçbir kursa & 32 & 73,73 & \multirow{6}{*}{4,725} & \multirow{6}{*}{4} & \multirow{6}{*}{0,317} \\
\hline & Bir kursa & 21 & 74,95 & & & \\
\hline & İki kursa & 20 & 75,1 & & & \\
\hline & Üç kursa & 14 & 65,64 & & & \\
\hline & Üçten fazla kursa & 48 & 58,86 & & & \\
\hline & Toplam & 135 & & & & \\
\hline \multirow{6}{*}{$\begin{array}{c}\text { Faktör } 3 \\
\text { Güvence Sağlama }\end{array}$} & Hiçbir kursa & 32 & 72,95 & \multirow{6}{*}{8,088} & \multirow{6}{*}{4} & \multirow{6}{*}{0,088} \\
\hline & Bir kursa & 21 & 59,88 & & & \\
\hline & İki kursa & 20 & 83,8 & & & \\
\hline & Üç kursa & 14 & 77,11 & & & \\
\hline & Üçten fazla kursa & 48 & 59,01 & & & \\
\hline & Toplam & 135 & & & & \\
\hline \multirow{6}{*}{$\begin{array}{c}\text { Faktör } 4 \\
\text { Bağımsızlık }\end{array}$} & Hiçbir kursa & 32 & 72,55 & \multirow{6}{*}{4,319} & \multirow{6}{*}{4} & \multirow{6}{*}{0,365} \\
\hline & Bir kursa & 21 & 61,69 & & & \\
\hline & İki kursa & 20 & 76,15 & & & \\
\hline & Üç kursa & 14 & 78,43 & & & \\
\hline & Üçten fazla kursa & 48 & 61,29 & & & \\
\hline & Toplam & 135 & & & & \\
\hline \multirow{5}{*}{$\begin{array}{c}\text { Faktör } 5 \\
\text { Kontrol Faaliyetleri }\end{array}$} & Hiçbir kursa & 32 & 78,98 & \multirow{5}{*}{6,965} & \multirow{5}{*}{4} & \multirow{5}{*}{0,138} \\
\hline & Bir kursa & 21 & 52,45 & & & \\
\hline & İki kursa & 20 & 62,15 & & & \\
\hline & Üç kursa & 14 & 71,21 & & & \\
\hline & Üçten fazla kursa & 48 & 68,98 & & & \\
\hline
\end{tabular}




\begin{tabular}{|l|c|c|c|c|c|c|}
\hline & Toplam & 135 & & & & \\
\hline \multirow{4}{*}{$\begin{array}{c}\text { Faktör 6 } \\
\text { Kontrol Ortamı }\end{array}$} & Hiçbir kursa & 32 & 71,17 & & & \\
\cline { 2 - 4 } & Bir kursa & 21 & 59,24 & & & \\
\cline { 2 - 4 } & İki kursa & 20 & 72,38 & \multirow{3}{*}{1,711} & \multirow{3}{*}{4} & \multirow{2}{*}{0,789} \\
\cline { 2 - 4 } & Üç kursa & 14 & 70,32 & & & \\
\cline { 2 - 4 } & Üçten fazla kursa & 48 & 67,22 & & & \\
\cline { 2 - 4 } & Toplam & 135 & & & & \\
\hline
\end{tabular}

Tablo 18'de, genel ortalamalar alınmıştır. Bazı faktörlerin ortalamaları yüksek çıkmasına rağmen, tablodeki göstericelere göre sig değerlerinin 0.05 den büyük olması değişkenler arasında anlamlı bir farkın olmadı ̆̆ belirlenmiştir.

Genel olarak faktörler arasında farklılık olmadığı görülmektedir. Faktörlerin denetim alanında eğitim kursalarının etkili olmadığı öngörülerek bu alanda önemli sayılmamıştır. Bu da aşağıdaki istatiksel verilerin çıktısına neden olmuştur:

a. Faktör 1 (Bilgi ve İletişim) bakımından elde edilen verilere yapılan Kruskal-Walliss testi sonucunda denetim alanında kursları sayısı seviyelerinin Rank ortalamaları arasındaki farklar istatistik olarak önemli değildir. $(\mathrm{P}<0,05)$ Dolayısıyla 19. hipotez reddedilmiştir.

b. Faktör 2 (Risk Değerlendirme) bakımından elde edilen verilere yapılan Kruskal-Walliss testi sonucunda Denetim alanında kursları sayısı1 seviyelerinin Rank ortalamaları arasındaki farklar istatistik olarak önemli değildir. $(\mathrm{P}<0,05)$ Dolayısıyla 20. hipotez reddedilmiştir.

c. Faktör 3 (Güvence Sağlama) bakımından elde edilen verilere yapılan Kruskal-Walliss testi sonucunda Denetim alanında kursları sayısı seviyelerinin Rank ortalamaları arasındaki farklar istatistik olarak önemli değildir. $(\mathrm{P}<0,05)$ Dolayısıyla 21. hipotez reddedilmiştir.

d. Faktör 4 (Bağımsızlık) bakımından elde edilen verilere yapılan Kruskal-Walliss testi sonucunda Denetim alanında kursları sayısı seviyelerinin Rank ortalamaları arasındaki farklar istatistik olarak önemli değildir. $(\mathrm{P}<0,05)$ Dolayısıyla 22. hipotez reddedilmiştir.

e. Faktör 5 ( Kontrol Faaliyetleri) bakımından elde edilen verilere yapılan Kruskal-Walliss testi sonucunda Denetim alanında kursları sayısı1 seviyelerinin Rank ortalamaları arasındaki farklar istatistik olarak önemli değildir. $(\mathrm{P}<0,05)$ Dolayısıyla 23. hipotez reddedilmiştir.

f. Faktör 6 (Kontrol Ortamı) bakımından elde edilen verilere yapılan Kruskal-Walliss testi sonucunda Denetim alanında kursları sayısı seviyelerinin Rank ortalamaları arasındaki farklar istatistik olarak önemli değildir. $(\mathrm{P}<0,05)$ Dolayısıyla 24. hipotez reddedilmiştir.

\subsection{Sadece Denetim ve İç Kontrol Bölümünde Çalışan Katılımcılara Yöneltilen Anket Sorularına İlişsin Veriler ve Değerlendirilmesi}

\subsubsection{Denetim Ve İç Kontrol Bölümü Çalışanlarına İlişkin Demografik Veriler}

Irak Sünni Vakfı Divanı teşkilat şemasında yer alan Denetim ve İç Kontrol Bölümü kurumun iç denetim faaliyetlerinin yapıldığ 1 yerdir. Her ne kadar bu bölümde çalışanların unvanı "iç denetçi" olmasa da yaptıkları faaliyetler iç denetim faaliyeti olduğundan kendilerine iç denetim faaliyetleriyle ilgili sorular sorulmuştur. Ayrıca bu kurumda "iç denetçi" unvanı bulunmamakla birlikte denetim ve iç kontrol bölümü çalışanları iç denetim faaliyeti yapmaktadır.

Aşağıdaki tablolar, denetim ve iç kontrol bölümü çalışanları tarafından cevaplandırılmakta olup, bu sorular sadece denetim bölümü personeli ile ilgilidir. Katılımcılara ilişkin demografik faktörler aşağıda tablolar halinde sunulmuştur.

Denetim bölümündeki katılımcıların cinsiyetlerine ilişkin veriler Tablo 19'da verilmektedir.

Tablo 19. Denetim ve İç Kontrol Bölümündeki Katılımcıların Cinsiyetine Göre Dağılım

\begin{tabular}{|c|c|c|}
\hline Cinsiyet & Katılımcı sayısı & Yüzde \\
\hline Erkek & 29 & $\% 53,7$ \\
\hline Kadın & 25 & $\% 46,3$ \\
\hline Toplam & 54 & $\% 100$ \\
\hline
\end{tabular}


Tablo 19'da görüldüğü üzere ankete katılanların yarıdan fazlasını $(\% 53,7)$ erkeler oluşturmaktadır.

Denetim ve iç kontrol bölümündeki katılımcıların yaşına ilişkin veriler Tablo 20'de verilmiştir.

Tablo 20. Denetim ve İç Kontrol Bölümündeki Katılımcıların Yaş Aralığına Göre Dağılım

\begin{tabular}{|c|c|c|}
\hline Yaş & Katılımcı sayısı & Yüzde \\
\hline 30 yaş ya da daha az & 11 & $\% 20,4$ \\
\hline $31-35$ yaş arası & 10 & $\% 18,5$ \\
\hline $36-40$ yaş arası & 18 & $\% 33,3$ \\
\hline $41-45$ yaş arası & 5 & $\% 9,3$ \\
\hline 46 yaş ve üstü & 10 & $\% 18,5$ \\
\hline Toplam & 54 & $\% 100$ \\
\hline
\end{tabular}

Tablo 20'de görüldüğü üzere kurumda genç bir denetim ekibinin bulunduğu söylenebilir. Denetimin tecrübe de gerektirdiği düşünüldüğünde kurum açısından bu durum olumlu değildir. Diğer yandan genç denetçilerin daha dikkatli olacağı varsayımında ise bu durum olumlu değerlendirilebilir. İç denetim ile ilgili aşağıdaki soruların cevaplanmasından genç denetim ekibinin olumlu veya olumsuz yönleri daha ayrıntılı değerlendirilebilecektir. verilmiştir.

Denetim ve iç kontrol bölümündeki katılımcıların deneyim yıllarına ilişkin veriler Tablo 21 'de

Tablo 21. Denetim ve İç Kontrol Bölümündeki Katılımcıların Deneyim Yıllarına İlişkin Veriler

\begin{tabular}{|c|c|c|}
\hline Deneyim Yıllarına & Katılımcı sayısı & Yüzde \\
\hline 5 yıl veya daha az & 10 & $\% 18,5$ \\
\hline 6-10 yıl arasında & 23 & $\% 42,6$ \\
\hline 11-15 yıl arasında & 16 & $\% 29,6$ \\
\hline 16 yıl ve üstü & 5 & $\% 9,3$ \\
\hline Toplam & 54 & $\% 100$ \\
\hline
\end{tabular}

Tablo 21'de de görüleceği üzere deneyim yılı temel alındığında katılımcıların yarından fazlası 10 yılın altında deneyime sahip bulunmaktadır. Yine tecrübeyi esas alan bir denetim anlayışında bu durum olumlu olmayacaktır.

Denetim ve iç kontrol bölümündeki katılımcıların eğitim durumlarına ilişkin veriler Tablo 22 'de verilmiştir.

Tablo 22. Denetim ve İç Kontrol Bölümündeki Katılımcıların Eğitim Durumlara İlişkin Veriler

\begin{tabular}{|c|c|c|}
\hline Eğitim Durumları & Katılımcı sayısı & Yüzde \\
\hline Lise & 7 & $\% 13,0$ \\
\hline önlisans & 10 & $\% 18,5$ \\
\hline Lisans & 35 & $\% 64,8$ \\
\hline Lisansüstü & 2 & $\% 3,7$ \\
\hline Toplam & 54 & $\% 100$ \\
\hline
\end{tabular}

Tablo 22'te, katılımcıların eğitim durumlarına göre dağılımları yer almaktadır. Buna göre ankete katılanlar. Eğitim durumları temel alındığında, büyük oranda lisans mezunudur $(\% 64,8)$ az miktarda da Lisansüstü mezunu bulunmaktadır $(\% 3,7)$, katılımcıların \%13,0'nün lise, \%18,5'nin ön lisans, \%64,8'nin lisans, \%3,7'nun Lisansüstü, olduğu görülmektedir. verilmiştir.

Denetim ve iç kontrol bölümündeki Katılımcıların iş ünvanına ilişkin veriler Tablo 23 'te

Tablo 23. Denetim ve İç Kontrol Bölümündeki Katılımcıların İş Ünvanına İlişkin Veriler

\begin{tabular}{|c|c|c|}
\hline İş Ünvanı & Katılımcı sayısı & Yüzde \\
\hline Memurlar & 8 & $\% 14,8$ \\
\hline
\end{tabular}




\begin{tabular}{|c|c|c|}
\hline Muhasebeci & 13 & $\% 24,1$ \\
\hline Muhasebe Denetçisi & 25 & $\% 46,3$ \\
\hline Yönetici & 8 & $\% 14,8$ \\
\hline Toplam & 135 & $\% 100$ \\
\hline
\end{tabular}

Tablo 23'te, katılımcıların "iş ünvanına" göre dağılımları yer almaktadır. Buna göre ankete katılanlar, İş ünvanı temel alındığında, katılımcıların \%14,8'nün memurlar, \%24,1'nün muhasebeci, $\% 46,3$ 'nün muhasebe denetici, \%14,8'nün yönetici, olduğu görülmektedir.

Denetim ve iç kontrol bölümündeki katılımcıların denetim alanında katıldıkları eğitim kursları veriler Tablo 24'te verilmiştir.

Tablo 24. Denetim ve İç Kontrol Bölümündeki Katılımcıların Denetim Alanında Katıldıkları Eğitim Kursları Sayısına İlişkin Veriler

\begin{tabular}{|c|c|c|}
\hline Denetim eğitim kursu & Katılımcı sayısı & Yüzde \\
\hline Hiçbir kurs & 4 & $\% 7,4$ \\
\hline Bir kurs & 9 & $\% 16,7$ \\
\hline İki kurs & 7 & $\% 13,0$ \\
\hline Üç kurs & 9 & $\% 16,7$ \\
\hline Üçten fazla kurs & 25 & $\% 46,3$ \\
\hline Toplam & 54 & $\% 100$ \\
\hline
\end{tabular}

Tablo 24'te de görüldüğü üzere denetim alanında verilen kurslara yoğun bir katılımın olmuştur. Genç ve deneyim y1lı az sayılabilecek denetim ekibinin tecrübe eksikliği düzenlenen kurslar ile giderilmeye çalışılmışıır. Araştırmadan elde edilen nitel verilere göre denetim kursları bazen kurum içi eğitim, bazen başka kurumlardan alınan eğitim, bazen de yurtdışı kurslar şeklinde gerçekleşmektedir. $\mathrm{Bu}$ kurslar hiyerarşik bir sıraya göre yapılmakta, kişilere kendilerini geliştirebilmeleri açısından firsat eşitliği yaratılmaktadır.

\subsubsection{Denetim Ve İç Kontrol Bölümü Çalışanlarının İç Denetim Faaliyetlerine İlişkin Görüşleri}

$\mathrm{Bu}$ başlıkta denetim ve iç kontrol bölümü çalışanlarının iç denetim faaliyetlerine ilişkin görüşlerine yer verilmiştir. Veriler tablolarda frekans yüzdeleri şeklinde sunulmuştur.

Denetim ve iç kontrol bölümü çalışanlarının anketin 31. sorusu olan "İç denetim görevlerimi baskı altında kalmaksızın yürütürüm” sorusuna verdikleri cevaplar Tablo 25 'te sunulmuştur.

Tablo 25. Anketin 31. Sorusunun Verileri ve Değerlendirilmesi

\begin{tabular}{|l|c|c|c|c|c|c|}
\hline $\begin{array}{l}\text { Anket Sorusu } \\
\text { (31. Soru) }\end{array}$ & \multicolumn{5}{|l|}{ İç denetim görevlerimi baskı altında kalmaksızın yürütürüm } \\
\hline Seçenekler & $\begin{array}{c}\text { Hiç } \\
\text { katılmıorum }\end{array}$ & Katılmıyorum & $\begin{array}{c}\text { Kısmen } \\
\text { katılıorum }\end{array}$ & Katılıyorum & $\begin{array}{c}\text { Kesinlikle } \\
\text { katılıyorum }\end{array}$ & Toplam \\
\hline Katılımcı sayısı & 0 & 2 & 20 & 24 & 8 & 54 \\
\hline Yüzde & $\% 0$ & $\% 3,7$ & $\% 37,0$ & $\% 44,4$ & $\% 14,8$ & $\% 100$ \\
\hline
\end{tabular}

Tablo 25'te, İç denetim görevlerimi baskı altında kalmaksızın yürütürüm önermesine katılımcıların 2'si $(\% 3,7)$ hariç olumlu görüş belirtmiştir. Bu durum denetim ve iç kontrol bölümü çalışanlarının görevlerini herhangi bir baskıya maruz kalmadan gerçekleştirdiğini göstermektedir. Diğer bir ifade ile iç denetimin unsurlarından olan "Bağımsızlık" unsurunun bu kurumda gerçekleştirildiğini göstermektedir. Bu durum ayrıca iç denetimin "güvence sağlama" unsuruna da uygundur. Güvence sağlama kurum dışındaki ilgililerin hak ve menfaatlarinin korunduğunu, bu korumanın da bağımsız bir birim tarafından güvenceye alındığını ifade etmektedir.

Denetim ve iç kontrol bölümü çalışanlarının anketin 32. sorusu olan "Tüm iç denetim faaliyetlerini gerçekleştirmek için yeterli bilgiye sahibim" sorusuna verdikleri cevaplar Tablo 26 ' da sunulmuştur. 
Tablo 26. Anketin 32. Sorusunun Verileri ve Değerlendirilmesi

\begin{tabular}{|l|c|c|c|c|c|c|}
\hline $\begin{array}{l}\text { Anket Sorusu } \\
\text { (32. Soru) }\end{array}$ & \multicolumn{5}{|c|}{ Tüm iç denetim faaliyetlerini gerçekleştirmek için yeterli bilgiye sahibim } \\
\hline Seçenekler & $\begin{array}{c}\text { Hiç } \\
\text { katılmıorum }\end{array}$ & Katılmıyorum & $\begin{array}{c}\text { Kısmen } \\
\text { katılıyorum }\end{array}$ & Katılıyorum & $\begin{array}{c}\text { Kesinlikle } \\
\text { katılıyorum }\end{array}$ & Toplam \\
\hline Katılımcı sayısı & 0 & 0 & 12 & 32 & 10 & 54 \\
\hline Yüzde & $\% 0$ & $\% 0$ & $\% 22,2$ & $\% 59,3$ & $\% 18,5$ & $\% 100$ \\
\hline
\end{tabular}

Tablo 26'da görüleceği üzere tüm iç denetim faaliyetlerini gerçekleştirmek için yeterli bilgiye sahibim önermesine olumsuz cevap veren olmamıştır. Bu durum da iç denetim konusunda denetim ekibinde kendine güven olduğunu göstermektedir.

Denetim ve iç kontrol bölümü çalışanlarının anketin 33. sorusu olan "Bana emanet edilen tüm denetim görevlerini zamanında yaparım” sorusuna verdikleri cevaplar Tablo 27'de sunulmuştur.

Tablo 27. Anketin 33. Sorusunun Verileri ve Değerlendirilmesi

\begin{tabular}{|l|c|c|c|c|c|c|}
\hline $\begin{array}{l}\text { Anket Sorusu } \\
\text { (33. Soru) }\end{array}$ & \multicolumn{6}{|l|}{ Bana emanet edilen tüm denetim görevlerini zamanında yaparım } \\
\hline Seçenekler & $\begin{array}{c}\text { Hiç } \\
\text { katılmıorum }\end{array}$ & Katılmıyorum & $\begin{array}{c}\text { Kısmen } \\
\text { katılıyorum }\end{array}$ & Katılıyorum & $\begin{array}{c}\text { Kesinlikle } \\
\text { katılıyorum }\end{array}$ & Toplam \\
\hline Katılımcı sayısı & 0 & 0 & 8 & 29 & 17 & 54 \\
\hline Yüzde & $\% 0$ & $\% 0$ & $\% 14,8$ & $\% 53,7$ & $\% 31,5$ & $\% 100$ \\
\hline
\end{tabular}

Tablo 27'de, tüm iç denetim faaliyetlerini gerçekleştirmek için yeterli bilgiye sahibim önermesine katılımcıların olumlu görüş belirttikleri görülmektedir. Denetim ve iç kontrol bölümü personelinin işlerini zamanında gerçekleştirdiklerini göstermektedir. $\mathrm{Bu}$ durum da iç denetim faaliyetlerinin iş yükünün denetim ekibine olması gerektiği şekilde dağıtıltığının bir göstergesi olabilir.

Denetim ve iç kontrol bölümü çalışanlarının anketin 34. sorusu olan "Tüm süreçleri ve görevleri plana uyduğundan emin olmak için gözden geçiririm” sorusuna verdikleri cevaplar Tablo 28'de sunulmuştur.

Tablo 28. Anketin 34. Sorusunun Verileri ve Değerlendirilmesi

\begin{tabular}{|l|c|c|c|c|c|c|}
\hline $\begin{array}{l}\text { Anket Sorusu } \\
\text { (34. Soru) }\end{array}$ & \multicolumn{5}{|c|}{ Tüm süreçleri ve görevleri plana uyduğundan emin olmak için gözden geçiririm } \\
\hline Seçenekler & $\begin{array}{c}\text { Hiç } \\
\text { katılmıorum }\end{array}$ & Katılmıyorum & $\begin{array}{c}\text { Kısmen } \\
\text { katılıyorum }\end{array}$ & Katılıyorum & $\begin{array}{c}\text { Kesinlikle } \\
\text { katılıyorum }\end{array}$ & Toplam \\
\hline Katılımcı sayısı & 0 & 0 & 18 & 27 & 9 & 54 \\
\hline Yüzde & $\% 0$ & $\% 0$ & $\% 33,3$ & $\% 50,0$ & $\% 16,7$ & $\% 100$ \\
\hline
\end{tabular}

Tablo 28 'de de görüldüğü üzere, tüm süreçleri ve görevleri plana uyduğundan emin olmak için gözden geçiririm önermesine olumlu cevap vermişlerdir. Denetim ve iç kontrol Bölümündeki personelin çoğunun planlanan şekilde çalışmayı ve aynı zamanda onları ilgilendiren yasaları ve talimatları uygulayarak incelediklerini göstermektedir.

Denetim ve iç kontrol bölümü çalışanlarının anketin 35. sorusu olan "Varlıkları korumak ve sağlamak için tüm prosedürlerin doğruluğunu kontrol ederim”" sorusuna verdikleri cevaplar Tablo 29'da sunulmuştur.

Tablo 29. Anketin 35. Sorusunun Verileri ve Değerlendirilmesi

\begin{tabular}{|l|c|c|c|c|c|c|}
\hline $\begin{array}{l}\text { Anket Sorusu } \\
\text { (35. Soru) }\end{array}$ & \multicolumn{5}{|c|}{ Varlıkları korumak ve sağlamak için tüm prosedürlerin doğruluğunu kontrol ederim } \\
\hline Seçenekler & $\begin{array}{l}\text { Hiç } \\
\text { katılmıyorum }\end{array}$ & Katılmıyorum & $\begin{array}{l}\text { Kısmen } \\
\text { katılıyorum }\end{array}$ & Katılıyorum & $\begin{array}{l}\text { Kesinlikle } \\
\text { katılıyorum }\end{array}$ & Toplam \\
\hline Katılımcı sayısı & 0 & 1 & 20 & 24 & 9 & 54 \\
\hline Yüzde & $\% 0$ & $\% 1,9$ & $\% 37,0$ & $\% 44,4$ & $\% 16,7$ & $\% 100$ \\
\hline
\end{tabular}


Tablo 29'da, Sünni Vakfı Divanı varlıklarının korunmasına yönelik olarak prosedürlerinin doğruluğunun kontrol edilmesine yönelik önermesine katılımciların orta derecenin biraz üzerinde katıldığı görülmektedir. Bu durum iç kontrol sistemine olan güveni göstermektedir. Ancak iç denetimin bir görevi de iç kontrol faaliyetlerinin etkinliği yanında iç kontrol prosedürlerinin de kalitesini denetlemektir. Bu yönüyle kurumda tam olarak iç denetim amaçlarına uygun hareket edildiğini söylemek zor olacaktır.

Denetim ve iç kontrol bölümü çalışanlarının anketin 36. sorusu olan "Çalışmalarımın, çalışma saatleri içerisinde tamamlanmasına özen gösteririm" sorusuna verdikleri cevaplar Tablo 30'da sunulmuştur.

Tablo 30. Anketin 36. Sorusunun Verileri ve Değerlendirilmesi

\begin{tabular}{|l|c|c|c|c|c|c|}
\hline $\begin{array}{l}\text { Anket } \\
\text { Sorusu (36. } \\
\text { Soru) }\end{array}$ & \multicolumn{6}{|c|}{ Çalışmalarımın, çalışma saatleri içerisinde tamamlanmasına özen gösteririm } \\
\hline Seçenekler & $\begin{array}{c}\text { Hiç } \\
\text { katılmıyorum }\end{array}$ & Katılmıyorum & $\begin{array}{c}\text { Kısmen } \\
\text { katılıyorum }\end{array}$ & Katılıyorum & $\begin{array}{c}\text { Kesinlikle } \\
\text { katılıyorum }\end{array}$ & Toplam \\
\hline $\begin{array}{l}\text { Katılımcı } \\
\text { sayısı }\end{array}$ & 0 & 0 & 7 & 30 & 17 & 54 \\
\hline Yüzde & $\% 0$ & $0 \%$ & $\% 13,0$ & $\% 55,6$ & $\% 31,5$ & $\% 100$ \\
\hline
\end{tabular}

Tablo 30'da da görüldüğü üzere, çalışmalarımın çalışma saatleri içerisinde tamamlanmasına özen gösteririm önermesine katılımcılar güçlü katılmışlardır. Bu durum denetim ekibinin eve iş götürmek veya mesai saatleri dışında iş yapmak istemediğini göstermektedir. İş disiplini açısından olumlu bir durum olarak değerlendirilebilir. Tablo 27 ve Tablo 30 birlikte değerlendirildiğinde katılımcıların işlerini savsaklamadığı ve iş saatleri içersinde işlerini tamamladıkları söylenebilir.

Denetim ve iç kontrol bölümü çalışanlarının anketin 37. sorusu olan "Yeterli denetim becerisine sahibim" sorusuna verdikleri cevaplar Tablo 31'de sunulmuştur.

Tablo 31. Anketin 37. Sorusunun Verileri ve Değerlendirilmesi

\begin{tabular}{|l|l|c|l|l|l|l|}
\hline $\begin{array}{l}\text { Anket Sorusu } \\
\text { (37. Soru) }\end{array}$ & \multicolumn{5}{|l|}{ Yeterli denetim becerisine sahibim } \\
\hline Seçenekler & $\begin{array}{l}\text { Hiç } \\
\text { katılmıyorum }\end{array}$ & Katılmıyorum & $\begin{array}{l}\text { Kısmen } \\
\text { katılıyorum }\end{array}$ & Katılıyorum & $\begin{array}{l}\text { Kesinlikle } \\
\text { katılıyorum }\end{array}$ & Toplam \\
\hline Katılımcı sayısı & 0 & 0 & 4 & 23 & 27 & 54 \\
\hline Yüzde & $\% 0$ & $\% 0$ & $\% 7,4$ & $\% 42,6$ & $\% 50,0$ & $\% 100$ \\
\hline
\end{tabular}

Tablo 31'de, yeterli denetim becerisine sahibim önermesine katılımcılar çok güçlü katılmışlardır. Bu durum katılımcıların göreve getirilirken iyi bir elemeden geçtĭgi, becerilerine göre atandığı sonucunu çıkarabilir. Ancak kişinin kendisiyle ilgili değerlendirmeler olduğu için sonuçlara ihtiyatl yaklaşmak gerekebilir.

Denetim ve iç kontrol bölümü çalışanlarının anketin 38. sorusu olan "İşimin üzerimde yarattığ1 baskıya dayanacak yüksek bir kapasiteye sahibim" sorusuna verdikleri cevaplar Tablo 32'de sunulmuştur.

Tablo 32. Anketin 38. Sorusunun Verileri ve Değerlendirilmesi

\begin{tabular}{|l|c|c|c|c|c|c|}
\hline $\begin{array}{l}\text { Anket Sorusu } \\
\text { (38. Soru) }\end{array}$ & \multicolumn{5}{|l|}{ İşimin üzerimde yarattığı baskıya dayanacak yüksek bir kapasiteye sahibim } \\
\hline Seçenekler & $\begin{array}{l}\text { Hiç } \\
\text { katılmıyorum }\end{array}$ & Katılmıyorum & $\begin{array}{l}\text { Kısmen } \\
\text { katılıyorum }\end{array}$ & Katılıyorum & $\begin{array}{l}\text { Kesinlikle } \\
\text { katılıyorum }\end{array}$ & Toplam \\
\hline Katılımcı sayısı & 0 & 0 & 21 & 26 & 7 & 54 \\
\hline Yüzde & $\% 0$ & $\% 0$ & $\% 38,9$ & $\% 48,1$ & $\% 13,0$ & $\% 100$ \\
\hline
\end{tabular}

Tablo 32'de, işimin üzerimde yarattığı baskıya dayanacak yüksek bir kapasiteye sahibim önermesine ise katılımcılar ortalamanın biraz üzerinde katılım göstermiştir. Denetim bütün işletmelerde olumsuz algısı olan bir süreçtir. Çünkü denetim sonucunda denetlediğiniz insanların eksikleri ortaya 
çıkacaktır. Bu durum denetçilere karşı olumsuz bir bakış geliştirecek ve üzerlerinde baskı yaratacaktır. Katılımcıların yaşı ve deneyimleri göz önünde bulundurulduğunda baskılara dayanacak kapasiteleri olduğunu ifade etmeleri önemlidir. Yine işe alınırken yapacakları faaliyetlerin kendilerine uygulayacağı baskıya dayanacak şekilde seçildikleri söylenebilir. Ayrıca çalışanların işleriyle ilgili yeterli deneyime sahip olduklarını ve işleriyle ilgili ortaya çıkacak zorluklarla nasıl başa çıkacaklarını bildikleri yorumu da yapilabilir.

Denetim ve iç kontrol bölümü çalışanlarının anketin 39. sorusu olan "İç denetim görevlerimi baskı altında kalmaksızın yürütürüm” sorusuna verdikleri cevaplar Tablo 33’te sunulmuştur.

Tablo 33. Anketin 39. Sorusunun Verileri ve Değerlendirilmesi

\begin{tabular}{|l|c|c|c|c|c|c|}
\hline $\begin{array}{l}\text { Anket Sorusu } \\
\text { (39. Soru) }\end{array}$ & \multicolumn{6}{|l|}{$\begin{array}{l}\text { Bize emanet edilen tüm görevleri yerine getirmek için ekip çalışması ruhuyla } \\
\text { meslektaşlarımla iş birliği yaparım }\end{array}$} \\
\hline Seçenekler & $\begin{array}{c}\text { Hiç } \\
\text { katılmıyorum }\end{array}$ & Katılmıyorum & $\begin{array}{c}\text { Kısmen } \\
\text { katılıyorum }\end{array}$ & Katılıyorum & $\begin{array}{c}\text { Kesinlikle } \\
\text { katılıyorum }\end{array}$ & Toplam \\
\hline Katılımcı sayısı & 0 & 0 & 2 & 14 & 38 & 54 \\
\hline Yüzde & $\% 0$ & $0 \%$ & $\% 3,7$ & $\% 25,9$ & $\% 70,4$ & $\% 100$ \\
\hline
\end{tabular}

Tablo 33'te görüleceği üzere, bize emanet edilen tüm görevleri yerine getirmek için ekip çalışması ruhuyla meslektaşlarımla iş birliği yaparım önermesine katılımcılar çok güçlü katılım göstermiştir. Katılımcıların kendileriyle ilgili her ne kadar olumlu düşünce içinde olsalar da ekip ruhuyla hareket edip birbirleriyle işbirliği yapmanın önemli olduğunun farkında olmaları önemli bir durumdur. İç denetimde benzer bakış açılarının olması denetimin standartlaşması denetlenenler açısından da önemlidir. A denetici ile B denetçisinin tavır ve değerlendirmelerinin farklılığı denetim kalitesini olumsuz etkileyebilir.

\section{SONUÇ VE ÖNERILER}

$\mathrm{Bu}$ çalışma Irak kamu kurumlarında iç denetim ve iç kontrol faaliyetlerine yönelik algı ve tutumları tespit etmek amacıyla Irak Sünni Vakfı Divanı Kurumu çalışanlarına anket şeklinde uygulanmıştır.

Çalışmanın sonucunda iç kontrolün risk değerlendirme faktörü ile iş ünvanı arasında istatistiki açıdan anlamlı bir ilişki çıkması dışında, demografik faktörlerle iç denetimin "bağımsızlık" ve "güvence" unsurları ile iç kontrolün "bilgi ve iletişim", "risk değerlendirme", "kontrol faaliyetleri" ve "kontrol ortamı" unsurları arasında istatistiki açıdan anlamlı bir ilişki tespit edilememiş̧ir. Bu durum katılımcıların çoğu konuda benzer tavırda olduğu ve benzer hareket ettiği konusunda bize ipucu vermektedir.

İç kontrol sisteminin etkinliği kadar iç kontrol sisteminin etkinliğini ve prosedürlerin güncelliğini denetleyen iç denetim sisteminin etkinliği de önemli olmaktadır. İki sistemin de etkinliği Irak Sünni Vakfı Divanı kurumsal yönetim ilkelerine uymaya gayret ettiğini ve kamu kaynaklarının etkin ve verimli kullanıldığını göstermektedir.

İç denetim ve iç kontrol sistemlerinden beklenen, bu faaliyetleri gerçekleştirirken sadece noksanlıkları tespit etmekten ziyade noksanlıkların iyileştirilmesi veya ileride karşılaşılmasının önlenmesi adına öneriler getirmeleridir. Burada gözden kaçırılmaması gereken husus bu sistemlerin icrai faaliyetlerinin olmaması gerektiğidir. Yapacakları öneriler bir zorunluluk değil, sadece süreci iyileştirmeye yönelik danışmanlıktır. İç denetim ve iç kontrol bir karar merci değil, ancak öneri ve danışma merci olabilir. Bu kapsamda iç denetim ve iç kontrol, vakfın faaliyetlerine değer katmak ve bu faaliyetleri gelişimine yardımcı olmak üzere tasarlanmış, bağımsız bir denetim, kontrol ve danışmanlık faaliyetidir.

Bunlarla birlikte getirilen düzenlenmelerde; iç denetim ve iç kontrol faaliyetleri yerine getirilirken bağımsız bir şekilde görev yapmalarını sağlayacak çalışma ortamının tesis edilmesi, raporlamalarının muhatabı olacak üst yönetim çalışanlarının belirlenmesi, bu faaliyetlerin gerçekleştirildiğine ilişkin çalışma kağıtları, risk odaklı hazırlanan denetim planı gibi unsurlara yer verildiği görülmektedir. Hali hazırda vakfita etkin bir iç denetim ve iç kontrol yapısı olduğu, bunun her 
geçen gün içerisinde geleneksel yapıdan değişimci bir yapıya dönüştüğü görülmektedir. Çalışmamızın sonucunda Irak Sünni Vakfı Divanı'nda iç denetim ve iç kontrol ile ilgili olarak birçok düzenlemeler getirilmiş̧ olduğu ve bunlarında uluslararası denetim standartlarının bir kısmı ile paralellik gösterdiği görülmüştür.

Genç sayılabilecek bir denetim ekibinin iç denetim faaliyetlerini gerçekleştirdiği Irak Sünni Vakfı Divanı'nda iç kontrol sistemi ve iç denetim sistemine yönelik olumlu bir algı ve inancın olduğundan söz edilebilir.

Bundan sonraki çalışmalarda Irak Sünni Vakfı Divanı veya benzeri devlet kurumlarında kurumsal yönetim ilkelerine yönelik algının da ölçülmesi yerinde olacaktır. Ayrıca bu kurumlarda kurumsal yönetim uygulamalarını bütünlemesi açısından adli muhasebe uygulamalarına yönelik çalışmaların yapılması da yararlı olabilir.

\section{KAYNAKÇA}

Adiloğlu, B. (2011). İç Denetim Süreci ve Kontrol Prosedürleri, İstanbul:Türkmen Kitabevi.

Akyel, R., (2010). Yönetimde İç Kontrol, İç Denetim ve Dış Denetim Fonksiyonlarının Birbirleri İle İlişkileri ve Türk Kamu Yönetiminde Uygulanmalarının Değerlendirilmesi. Sosyal Bilimler Enstitüsü Dergisi, 19(3), 1-22.

Bütçe ve Mali Kontrol Genel Müdürlüğü (BÜMKO), Üst Yöneticiler İçin İç Kontrol ve İç Denetim

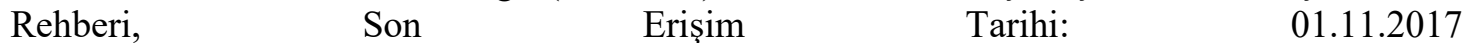
https://kontrol.bumko.gov.tr/Eklenti/3666,ustyonpdf.pdf

DOĞAN, S., \& BURGAZLIOĞLU, E. (2015). İç Kontrol Sistemi Ve Özel Bir Hastanede Uygulaması. Kırklareli Üniversitesi İktisadi ve İdari Bilimler Fakültesi Dergisi, 4(1), 18-33.

Ergin, H., vd. (2016). KİT’lerde Kurumsal Yönetim Etkinliğinin Arttırılmasında İç Kontrol Ve İç Denetim Faaliyetlerinin Rolü: Bir Araştırma. Dumlupınar Üniversitesi Sosyal Bilimler Dergisi. (49), 1-28.

El-Baaj, Q.M.A. (2011). تقييم نظم الرقابة الداخلية في وحدات قطاع التعليم العالي (Evaluating the İnternal Observation Systems in the Higher Education Sector in Iraq). AL-Qadisiyah Journal For Administrative and Economic Sciences. 13(4), 72-95.

Erkan, M. (2000). Muhasebe Denetim, 1. Bask1, Ankara:Alf Yayınları.

Günal, A.A. (2010). İç Kontrol Sistemi ve Üretim İşletmelerinde Bir Uygulama. Ankara:TÜRMOB Yayınları.

Güriş, S., \& Astar, M. (2015). Bilimsel Araştırmalarda SPSS ile İstatistik, 2. Basım, İstanbul:Der Yayınları.

Haftac1, V., (2014). Muhasebe Denetimi, 3. Bask1, Kocaeli:Umuttepe Yayınlar1.

Irak Cumhuriyeti Mali Kontrol Bürosu, Teknik İşler ve Araştırmalar Bölümü. Son Erişim Tarihi: 01.11.2017, https://www.fbsa.gov.iq/uploads/files/attachments/istirshad_guid.pdf

Irak Cumhuriyeti Sünni Vakfı Divanı. Son Erişim Tarihi: 01.11.2017, sunniaffairs.gov.iq

Izz El-Din, O. (2015). The Impact of Internal Control System Effectiveness on Internal Auditor Performance: A Field Study on Jordanian Private Universities. (Unpublished Master Dissertation) Middle East University, Jordan.

Kurnaz, N., \& Çetinoğlu, T. (2010). İç Denetim Güncel Yaklaşımlar. 1. Baskı. İstanbul: Umuttepe Yayınları.

Moeller, R. (2009). Brink's Modern Internal Audit. Eighth Edition. New Jersey:John Wiley \& Sons, Inc, Hoboken.

Mohamud, H.A. (2013). Internal Auditing Practices and Internal Control System in Somali Remittance Firms. International Journal of Business and Social Science. 4(4). 165-172 
Önder, M. (2008). Türk Hukukunda İç Denetim ve Uluslararası Standartlara Uyumu. 1. Bask1. Ankara:Asil Yayın.

Özbek, Ç. (2012). İç Denetim. İstanbul:Türkiye İç Denetim Enstitüsü Yayınları,

Özkardeş, L. (2017). Kurumsal Firmaların İç Kontrol, İç Denetim ve Riske Yaklaşımları. Journal of Yasar University. 12(47). 192-201

Pickett, K. H. (2011). The Assantial Guide To Internal Auditing. A John Wiley \& Sons, Ltd.

Kardeş Selimoğlu, S. vd., (2014). Muhasebe Denetimi. 4. Baskı. Ankara:Gazi Kitabevi.

Wilson, J.D. \& Root, S.J. (1989). Internal Auditing Manual, Boston:Warren, Gorham \& Lamont. 